\title{
The Future of Exogenous Surfactant Therapy
}

\author{
Douglas F Willson MD and Robert H Notter MD PhD
}

\author{
Introduction \\ A Brief History \\ Pharmaceutical Surfactants \\ The Biologic Plausibility of Surfactant Therapy in ALI/ARDS \\ Additional Surfactant Can Overcome Surfactant Inhibition/Dysfunction \\ Animal Studies of Surfactant \\ Human Studies \\ Summary and the Future of Surfactant Therapy
}

\begin{abstract}
Since the identification of surfactant deficiency as the putative cause of the infant respiratory distress syndrome (RDS) by Avery and Mead in 1959, our understanding of the role of pulmonary surfactant in respiratory physiology and the pathophysiology of acute lung injury (ALI) has advanced substantially. Surfactant replacement has become routine for the prevention and treatment of infant RDS and other causes of neonatal lung injury. The role of surfactant in lung injury beyond the neonatal period, however, has proven more complex. Relative surfactant deficiency, dysfunction, and inhibition all contribute to the disturbed physiology seen in ALI and acute respiratory distress syndrome (ARDS). Consequently, exogenous surfactant, while a plausible therapy, has proven to be less effective in ALI/ ARDS than in RDS, where simple deficiency is causative. This failure may relate to a number of factors, among them inadequacy of pharmaceutical surfactants, insufficient dosing or drug delivery, poor drug distribution, or simply an inability of the drug to substantially impact the underlying pathophysiology of ALI/ARDS. Both animal and human studies suggest that direct types of ALI (eg, aspiration, pneumonia) may be more responsive to surfactant therapy than indirect lung injury (eg, sepsis, pancreatitis). Animal studies are needed, however, to further clarify aspects of drug composition, timing, delivery, and dosing before additional human trials are pursued, as the results of human trials to date have been inconsistent and largely disappointing. Further study and perhaps the development of more robust pharmaceutical surfactants offer promise that exogenous surfactant will find a place in our armamentarium of treatment of ALI/ARDS in the future. Key words: surfactant; infant respiratory distress syndrome; RDS; acute lung injury; ALI; acute respiratory distress syndrome; ARDS; neonatal. [Respir Care 2011;56(9):1369-1386. (C) 2011 Daedalus Enterprises]
\end{abstract}

\section{Introduction}

Exogenous lung surfactants are among the most studied drugs in medicine. Surfactant therapy is currently a main-

Dr Willson is affiliated with the Department of Pediatrics, University of Virginia Children's Hospital, Charlottesville, Virginia. Dr Notter is affiliated with the Departments of Pediatrics and Environmental Medicine, University of Rochester, Rochester, New York.

Dr Willson presented a version of this paper at the 47th RESPIRATORY CARE Journal Conference, "Neonatal and Pediatric Respiratory Care: What Does the Future Hold?" held November 5-7, 2010, in Scottsdale, Arizona. stay in neonatal care, where its use has been associated with a significant reduction in the morbidity and mortality accompanying premature birth. Given the physiologic ne-

\footnotetext{
Dr Willson has disclosed relationships with ONY Inc and Pneuma Pharmaceuticals.

Correspondence: Douglas F Willson MD, Department of Pediatrics, University of Virginia Children's Hospital, Charlottesville VA 22908-0386. E-mail: dfw4m@virginia.edu.
}

DOI: $10.4187 /$ respcare.01306 
cessity of pulmonary surfactant for normal breathing, and its demonstrated deficiency in prematurity, the efficacy of exogenous surfactant therapy in pre-term infants is predictable. There is also evidence of surfactant dysfunction in many forms of acute pulmonary injury in term infants, children, and adults as well, but the evidence of therapeutic efficacy for exogenous surfactant outside of the neonatal period is more limited.

This review discusses the evidence for surfactant dysfunction in acute lung injury (ALI) and the acute respiratory distress syndrome (ARDS), and clinical studies to date of exogenous surfactant therapy in term infants, children, and adults. While therapeutic use of surfactant in acute pulmonary injury outside of the neonatal period enjoys biologic plausibility and has achieved success in treating term infants and children with several direct types of acute pulmonary injury, controlled clinical studies have been largely unsuccessful in adults with ALI/ARDS. Possible reasons for this and future directions in continuing surfactant research will be discussed.

\section{A Brief History}

If you would understand anything, observe its beginning and its development. - Aristotle

The phenomenon of surface tension and its effects on the pressure drop across an interface separating 2 phases of matter was defined mathematically in the early $1800 \mathrm{~s}$ by the Law of Young and Laplace. Applied to the pulmonary alveoli, this law states that the pressure drop required to inflate or maintain these air sacs at a given size is directly proportional to their surface tension and inversely proportional to their radius. The work of breathing, which generates the necessary pressure drop, is thus similarly directly proportional to surface tension. The important contribution of surface tension forces to lung mechanics was documented in 1929 , when von Neergaard ${ }^{1}$ showed that it took higher pressure to inflate excised animal lungs with air (when surface tension was present) than with saline (when surface tension forces were minimal because there was no longer a liquid-air interface). Analysis of these data indicated that over half of the pressure drop needed to inflate the normal lung was to overcome surface tension forces.

An equally important fact not appreciated at the time of von Neergaard's experiments was that pulmonary surface tension forces would actually be much larger (and in fact physiologically unsupportable) if surface tension in the normal lungs were not greatly reduced by lung surfactant. Surface-active substances (surfactants) lower surface tension biophysically by virtue of an amphipathic (polar/nonpolar) molecular structure, and the presence of surfactants
Table 1. Composition of Natural Surfactant (\%)

\begin{tabular}{|c|c|c|}
\hline Protein lipid & & $90-95$ \\
\hline Phospholipids (\% of total lipid) & 90-95 & \\
\hline Phosphatidylcholine & 80 & \\
\hline Anionic phospholipids & 15 & \\
\hline Other phospholipids & 5 & \\
\hline Neutral lipids & $5-10$ & \\
\hline Protein & & $5-10$ \\
\hline \multicolumn{3}{|l|}{$\begin{array}{l}\text { Biophysically active apoproteins } \\
\quad \text { (SP-A, SP-B, SP-C) }\end{array}$} \\
\hline$\overline{\text { (Data from Reference } 5 \text {.) }}$ & & \\
\hline
\end{tabular}

in the lungs is essential for normal respiration. The existence of lung surfactant in air-breathing animals was documented in the mid-1950s by Pattle ${ }^{2,3}$ and Clements. ${ }^{4}$ This complex material, a mixture of lipids and specific proteins, is one of the most powerful surface-active substances known. Table 1 shows representative compositional percentages for large aggregate surfactant isolated from alveolar washings via sedimentation and density-gradient centrifugation or type II cell lamellar bodies from multiple animal species. ${ }^{5}$ The major phosphatidylcholine fraction of total surfactant phospholipid is about 55\% saturated (dipalmitoylphosphatidylcholine plus other saturated phosphatidylcholines) and $45 \%$ unsaturated. The anionic phospholipids group includes phosphatidylglycerol, phosphatidyl-inositol, and phosphatidylserine. Other phospholipids include phosphatidylethanolamine and sphingomyelin. Neutral lipids include cholesterol and cholesterol esters plus diglycerides/triglycerides.

By lowering and varying alveolar surface tension, lung surfactant maintains a low physiological work of breathing, stabilizes small alveoli against collapse (atelectasis), improves the overall uniformity of alveolar inflation, and reduces the hydrostatic driving force for pulmonary edema. Details of the discovery, composition, and physiological actions of pulmonary surfactant are reviewed elsewhere..$^{5,6}$

Because of its necessity for normal respiration, a deficiency or dysfunction of lung surfactant results in severe respiratory failure. Soon after the discovery of lung surfactant, Avery and Mead ${ }^{7}$ in 1959 suggested that surfactant deficiency might account for infant respiratory distress syndrome (RDS). Subsequent studies identified the most prevalent phospholipid component of lung surfactant as dipalmatoylphosphatidylcholine (DPPC), but attempts to treat pre-term infants with RDS with aerosolized DPPC were completely unsuccessful. ${ }^{8-10}$ It is now clear that DPPC alone is a biophysically inadequate lung surfactant, and that the aerosol delivery methods used also delivered very little DPPC to the alveoli. This was not recognized at the time, and the failure of nebulized DPPC surfactant therapy led many to return to the previous clinical hypothesis of 

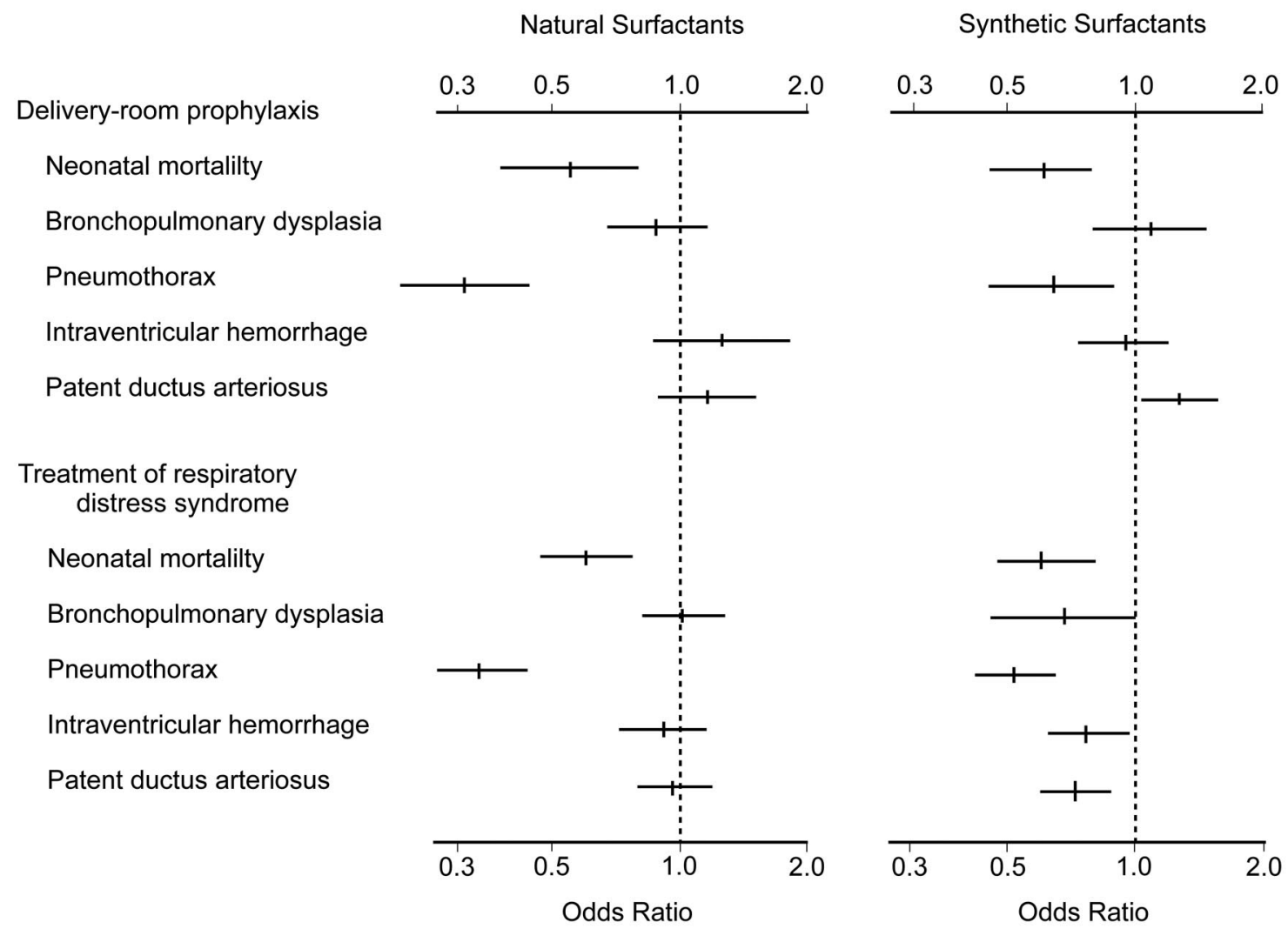

Fig. 1. Odds ratios and 95\% confidence intervals from meta-analyses of clinical trials that found benefits from exogenous surfactant therapy for preventing or treating infant respiratory distress syndrome (RDS). Eight trials (930 infants) administered animal-derived surfactant prophylactically in the delivery room, 12 trials (1,451 infants) administered animal-derived surfactant in the intensive care nursery to treat RDS, 7 trials (1,492 infants) administered synthetic surfactant prophylactically in the delivery room, and 5 trials (2,126 infants) administered synthetic surfactant in the intensive care nursery to treat RDS. Neonatal mortality was defined as death from any cause before the 29th day of life. Bronchopulmonary dysplasia was defined as the need for oxygen, with or without assisted ventilation, together with typical radiographic changes on the 28th day of life. Intraventricular hemorrhage was defined as severe hemorrhage, categorized as either grade III (extensive intraventricular hemorrhage with ventricular enlargement) or grade IV (intraparenchymal hemorrhage). (Adapted from Reference 14, with permission.)

pulmonary ischemia as the cause of RDS. ${ }^{10}$ This misconception delayed further efforts to develop surfactant therapy for well over a decade. Acceptance that surfactantdeficiency was responsible for RDS did not occur until after Enhorning and colleagues ${ }^{11,12}$ demonstrated in 1973 that tracheal instillation of active whole surfactant from adult animals into pre-term rabbit pups could restore normal lung function. Even then, several more years of supportive animal studies were needed before Fujiwara et al first demonstrated the therapeutic value of exogenous surfactant in human infants with RDS in $1980 .{ }^{13}$

Multiple clinical trials in pre-term infants were conducted in the 1980s, following Fujiwara et al's initial successful study.5,14,15 These trials demonstrated unequivocally that exogenous surfactant improved survival and decreased morbidity in RDS (Fig. 1). Indeed, in the first year after the FDA approved surfactant therapy in the United States there was a notable decrease in neonatal mortality, primarily related to improved survival of pre- term infants. ${ }^{14}$ Surfactant therapy is now the standard of care for the prevention and treatment of RDS. As described below, the most active surfactant drugs currently approved for treatment of RDS are animal-derived preparations that contain surfactant lipids and one or more of the active hydrophobic surfactant proteins (SP-B or SP-C). In addition, several synthetic exogenous surfactants are under clinical study and laboratory research. ${ }^{16-24}$

\section{Pharmaceutical Surfactants}

Before delving too deeply into the potential merits of surfactant therapy in ALI/ARDS, it is important to recognize that there are several different types of pharmaceutical surfactants, and their differences may have important implications for their efficacy. Endogenous pulmonary surfactant is a complex mixture of lipids (primarily phospholipids) and specific apoproteins that is highly conserved across mammalian species. The degree of resemblance of 
pharmaceutical surfactants to native surfactant is highly variable, and clinical preparations can be divided conceptually into 3 groups ${ }^{5,16,18,25}$ :

I: Organic solvent extracts of lavaged lung surfactant from animals (bovactant, bovine lung extract surfactant, calfactant)

II: Organic solvent extracts of processed animal lung tissue, with or without additional synthetic additives (poractant alfa, beractant or surfactant-TA)

III: Synthetic preparations that do not contain surfactant material from animal lungs (ALEC, colfosceril palmitate, lucinactant, recombinant protein $\mathrm{C}$ surfactant)

Surfactants in categories I and II are sometimes classified as natural surfactants, and have the closest compositional analogy to endogenous surfactant. Category I surfactants are obtained directly from alveolar lavage fluid, and in principle contain all the surfactant phospholipids plus the hydrophobic surfactant proteins SP-B and SP-C in close approximation to the natural ratio (the hydrophilic surfactant proteins SP-A and SP-D are removed by organic solvent extraction in all category I and category II surfactants). Surfactant preparations in category II also contain surfactant phospholipids and one or both of the hydrophobic surfactant proteins, but in addition may contain cellular lipids and/or fragments of cellular proteins because they are derived from processed lung tissue. Moreover, during processing, the content of functionally important surfactant proteins can be affected (eg, SP-B is reduced to a very low level in beractant during its preparation from bovine lungs ${ }^{26-29}$ ).

Category III synthetic lung surfactants have conceptual advantages in purity, reproducibility, manufacturing quality control efficiency, and scale-up economy compared to animal-derived surfactants. They are also free from the risk of prion transmission, and are not subject to cultural and religious issues that can affect bovine or porcine surfactants. However, it has proved to be challenging to bioengineer fully synthetic surfactants having high activity equivalent to native surfactant. Two early protein-free synthetic surfactants (ALEC and colfosceril palmitate) are no longer used clinically because their activity is substantially less than existing animal-derived surfactants. ${ }^{24,25,27}$ Two synthetic surfactants currently under clinical study are lucinactant (KL4 surfactant) and recombinant protein C surfactant (recombinant SP-C surfactant). However, the 21residue KL4 peptide in lucinactant only roughly approximates the overall ratio of hydrophobic to charged residues in SP-B, without any direct sequence analogy to the native protein. Also, recombinant protein $\mathrm{C}$ surfactant contains modified recombinant SP-C but no SP-B component.

SP-B appears to be the more important of the 2 hydrophobic surfactant proteins. Extensive laboratory studies have documented that SP-B is more active than SP-C in interacting biophysically with lipids in lung surfactant ac- tivity, ${ }^{29-38}$ and supplementation with SP-B or synthetic SP-B peptides increases the activity of surfactants containing only SP-C in animal models. ${ }^{26,29,39}$ Knock-out mice with isolated SP-B deficiency die shortly after birth, of respiratory failure, ${ }^{40}$ and human infants with SP-B mutations do not survive beyond the first days of life without surfactant replacement (and ultimately lung transplantation). ${ }^{28,41-43}$ An elegant series of experiments by Ikegami et $\mathrm{al}^{44}$ using a conditional knock-out mouse model demonstrated that adult mice rendered acutely deficient in SP-B develop severe respiratory distress with evidence of surfactant dysfunction and pulmonary inflammation. Mice left SP-B deficient died with pathology resembling ARDS, but the abnormalities were reversed and the mice survived if SP-B synthesis was restored. Interestingly, these mice maintained normal levels of the SP-C protein during study. ${ }^{44}$

Recent advances in molecular bioengineering and peptide chemistry also provide the potential to design new even more active synthetic lung surfactants, and several approaches are being studied. 19,20,24,45 These include fully synthetic surfactants bioengineered to contain peptides that incorporate functionally crucial structural regions in human SP-B, such as the highly active super mini-B peptide recently reported by Waring and colleagues. ${ }^{22}$ New synthetic surfactants can also contain peptide components that incorporate active regions of other human surfactant apoproteins in combination with SP-B peptides. ${ }^{19}$ Synthetic exogenous surfactants containing super mini-B or related peptides can also include novel lipids designed to have further beneficial molecular properties such as phospholipase-resistance. One particularly active synthetic lipid analog of this kind is DEPN-8, a phospholipase-resistant diether lipid developed by Notter and co-workers. ${ }^{19,21,23,46,47}$ Synthetic surfactants containing DEPN-8 or other phospholipase-resistant lipids plus active SP-B peptides have the potential for particular utility in ALI/ ARDS, ${ }^{19,21,23,48-50}$ where these lytic enzymes can be elaborated in high concentrations during the inflammatory response in injured lungs. ${ }^{51-57}$

Regardless of category (animal-derived or synthetic), the requirements for an effective therapeutic surfactant in ALI/ARDS are more stringent than is the case for RDS. To treat severe acute inflammatory lung injury, exogenous surfactant must have the greatest possible activity and resistance to inhibition or inactivation. Compositional differences among pharmaceutical surfactants are a major factor in clinical efficacy. The lack of efficacy of surfactant therapy in several randomized clinical trials in adults with ALI/ARDS may relate at least in part to inadequacies of the specific surfactant drugs used. For example, the protein-free exogenous surfactant colfosceril palmitate has some activity in treating RDS, ${ }^{58-61}$ but it is lower than that of apoprotein-containing animal surfactants such as calfactant, ${ }^{62,63}$ and colfosceril palmitate has no clinical benefits in 


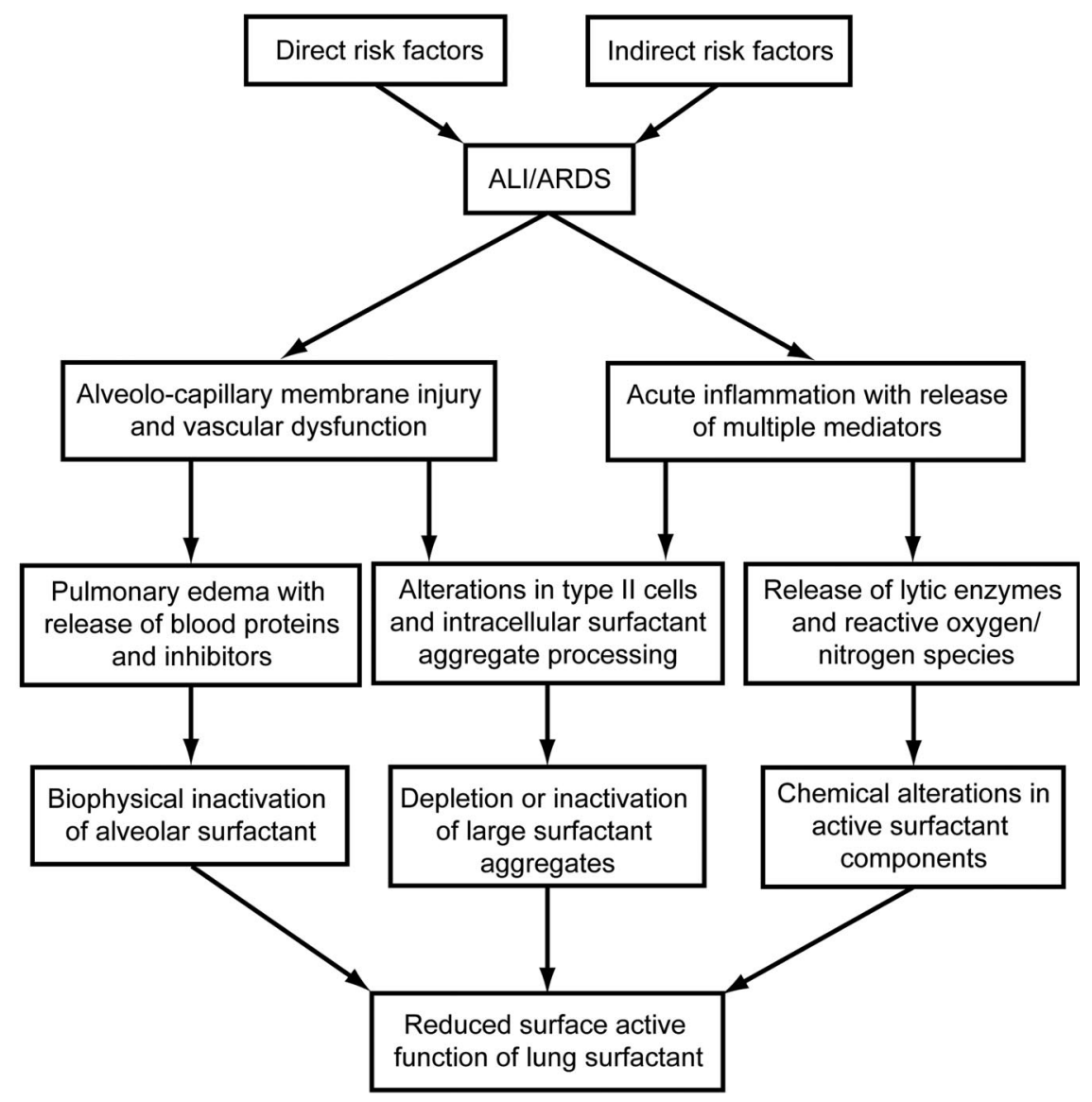

Fig. 2. Pathways that can contribute to surfactant dysfunction in acute inflammatory pulmonary injury (acute lung injury [ALI] and acute respiratory distress syndrome [ARDS]). Initiators of lung injury can act either from the alveolar side (direct lung injury) or from the vascular side (indirect or extra-pulmonary lung injury). Both the direct and indirect etiologies induce pulmonary inflammation, alveolo-capillary membrane injury, permeability edema, and reactive vasoconstriction or other vascular dysfunction. In conjunction with this complex pathology, surfactant dysfunction can occur via the multiple mechanisms shown in the figure and described in the text. The resulting loss of surface-active function contributes to decreased lung volume, decreased compliance, severe ventilation-perfusion mismatching, and acute respiratory failure. (Data from References 5 and 72.)

adults with ARDS. ${ }^{64}$ Similarly, beractant has minimal benefits in adults with sepsis-induced ARDS, ${ }^{65}$ which correlates with its very low content of active SP-B. However, beractant still has substantial activity because of its content of SP-C, ${ }^{29}$ and it is efficacious in treating premature infants with RDS and term infants with acute respiratory failure from meconium aspiration lung injury, as detailed below. $66-69$

\section{The Biologic Plausibility of Surfactant Therapy in ALI/ARDS}

Surfactant replacement therapy in RDS makes intuitive sense, because surfactant is deficient in the premature lung and exogenous surfactant directly corrects this deficiency. The situation in ALI/ARDS, however, is more complex. Unlike RDS, surfactant dysfunction rather than deficiency is the more important contributor to ALI/ARDS pathophysiology. In ALI/ARDS an initially functional pulmo- nary surfactant system becomes collateral damage to whatever primary process injures the lung, irrespective of whether the injury originates on the alveolar side (direct lung injury such as from aspiration, pulmonary infection, oxygen or toxicity) or from the vascular side (indirect or extra-pulmonary lung injury such as from sepsis, shock, pancreatitis, burn injury, or multiple blood transfusions). During both direct and indirect lung injury, initially active surfactant can be rendered dysfunctional by a number of mechanisms (Fig. 2). Specific mechanisms of surfactant dysfunction in lung injury include ${ }^{5,70-72}$ :

- Inhibition of surfactant biophysical function by plasma proteins ${ }^{27,35,73-79}$ or other blood components such as fatty acids, ${ }^{79-84}$ that can leak into the alveolar spaces as a result of alveolo-capillary membrane injury and decreased barrier integrity

- Alterations in alveolar surfactant aggregates, whereby 
the most active large aggregate forms of surfactant are reduced in activity and/or percent content, while less active small aggregate forms of surfactant become more prevalent ${ }^{72,80,85-93}$

- Biophysical inhibition and/or chemical alteration of components in the alveolar surfactant film induced by cell membrane lipids, ${ }^{75,79,83,94-96}$ meconium, ${ }^{97}$ or other substances present during the innate pulmonary inflammatory response, such as proteases, ${ }^{98}$ phospholipases, ${ }^{23,99,100}$ or reactive oxygen/nitrogen species ${ }^{84,101-103}$

- Altered synthesis, secretion, or composition of active surfactant due to injury-induced changes in alveolar type II pneumocytes, which are the primary cells of lung surfactant metabolism ${ }^{104-107}$

All of the above mechanistic pathways of surfactant dysfunction are potentially present in the complex pathology of ALI/ARDS lung injury, and abnormalities in surfactant activity, large aggregate content, or composition have been well documented in bronchoalveolar lavage from patients with ALI/ARDS. ${ }^{92,93,108-113}$ Regardless of mechanism, the practical consequences of surfactant dysfunction in ALI/ARDS are not dissimilar to those in RDS. As a result of decreased surfactant activity, the lungs become less compliant, develop progressive loss of aerated volume, and manifest a worsening ventilation/perfusion mismatch. Hypoxia, respiratory failure, and the need for respiratory support ensue. Additionally, ALI/ARDS involves pulmonary inflammation and vascular dysfunction that can substantially impact overall patient outcomes and response to therapy. Systemic inflammation and multi-organ (extrapulmonary) pathology are particularly prominent in indirect forms of ALI/ARDS. The complex pathophysiology of ALI/ARDS is reviewed elsewhere. ${ }^{18,114-121}$

It is important for therapeutic applications to recognize that lung injury in ALI/ARDS is a dynamic process. Initial acute inflammation and surfactant dysfunction can evolve to a state where pulmonary pathology is heterogeneous and includes important aspects of chronic or sub-chronic inflammation, fibroproliferative repair, vascular remodeling, and so on. Within several days following an acute pulmonary injury, type II pneumocytes also undergo proliferation and can subsequently dedifferentiate to type I cells (type II pneumocytes are stem cells for the alveolar epithelium in addition to their surfactant metabolic roles). Early interventions with exogenous surfactant therapy are likely to be most effective before type II cell changes and other chronic or sub-chronic aspects of fibroproliferative pathology are prominent in the lungs. The evolution of lung injury may also be exacerbated by positive-pressure ventilation-so-called ventilator-induced lung injury (VILI) - further complicating the pathophysiology. ${ }^{122-125}$ A major benefit of early exogenous surfactant may be to minimize or ameliorate VILI. Improved compliance and better aeration at lower pressures and volumes with early surfactant administration may prevent a vicious circle of ventilator-induced injury that leads to increasingly and more injurious levels of ventilator support, leading to further iatrogenic lung injury.

\section{Additional Surfactant Can Overcome Surfactant Inhibition/Dysfunction}

Because lung surfactant acts on respiratory mechanics by virtue of its surface-active properties, measurements of these surface-active properties in vitro have direct physiological importance and provide highly relevant insights about the rationale for surfactant-based therapies. Multiple in vitro studies have shown that pulmonary surfactant's ability to lower surface tension is impaired by exposure to albumin, hemoglobin, lyso-phospholipids, fatty acids, and other substances that leak into the alveolar space in association with injury to the alveolar-capillary membrane, as described in the preceding section. ${ }^{27,35,73-84}$ Importantly, those studies also document that inhibitor-induced inactivation can be overcome by raising surfactant concentration, offering a plausible mechanism whereby exogenous surfactant administration might improve lung function after acute injury. The ability of exogenous surfactants to overcome inhibition in vitro depends not only on surfactant concentration, but also on their content of essential apoproteins, particularly SP-B. Exogenous surfactants with higher contents of SP-B generally have greater activity and better inhibition resistance than those with little or no SP-B. ${ }^{5}$ This is particularly relevant clinically, because the 3 major surfactant drugs studied to date in controlled trials in adults with ARDS contain either no SP-B (colfosceril palmitate and recombinant protein $C$ surfactant) ${ }^{64,126,127}$ or minimal SP-B (beractant). ${ }^{65}$

\section{Animal Studies of Surfactant}

Although the existence of surfactant dysfunction in ALI/ ARDS and the fact that it can be overcome in vitro by increasing the concentration of active surfactant provide a conceptual rationale for surfactant replacement, evidence from animal studies is also required to support human therapy. Animal model studies of ALI/ARDS have some practical limitations, including:

- They largely evaluate short-term outcomes such as oxygenation improvement or acute changes in lung histology.

- The injury initiators and species used are diverse and complicate comparisons.

- Some models, such as saline lavage (one of the most 
commonly used ALI/ARDS models), resemble RDS more than ALI/ARDS.

- It is difficult to assess potentially crucial clinical factors such as VILI in short-term animal experiments.

Despite these shortcomings, animal models are an invaluable complement to clinical trials in humans. Animal models of ALI/ARDS can be divided into direct and indirect injury models. In analogy with clinical ALI/ARDS, direct models employ injuries originating on the alveolar side of the alveolar-capillary membrane (eg, animals given pneumonia, acid aspiration, intratracheal toxin administration, hyperoxic exposure). Animals with isolated pulmonary contusion from focused blunt closed-chest trauma are also conceptually in the direct injury category. Indirect ALI/ARDS models involve systemic injuries originating on the capillary side of the alveolar-capillary membrane (eg, animals given sepsis, intravenous oleic acid, or other systemic toxin administration). The response to exogenous surfactant in direct lung-injury models has generally been positive, whereas treatment responses are less favorable in indirect injury models. $5,71,72$

One classic direct ALI/ARDS lung-injury model involves mechanically ventilated animals undergoing repeated lung lavage with warmed saline until a level of hypoxia consistent with ARDS results. This model has been studied in several mammalian species, and the response to instilled active exogenous surfactant has been consistently positive. ${ }^{22,39,128-137}$ However, lung lavage primarily induces surfactant deficiency resembling RDS rather than ALI/ARDS, although superimposed injury from in vivo lavage and mechanical ventilation is also present. Other animal models of direct pulmonary ALI/ARDS have also responded favorably to active exogenous surfactant. Experiments in 2 models of viral infection, one with Sendai virus in mice, ${ }^{138}$ and another with influenza A virus, ${ }^{139}$ show improved oxygenation and lung histology with exogenous surfactant.

Exogenous surfactant therapy is similarly beneficial in animals with pneumonia from Pneumocystis carinii, ${ }^{140}$ group B streptococcus, ${ }^{141}$ and acid aspiration pneumonitis. ${ }^{142-145}$ Direct lung injury from tracheally instilled lipopolysaccharide in animals also responds favorably to exogenous surfactant administration, ${ }^{146,147}$ and there was significant favorable response to exogenous surfactant in animals with acute hyperoxic injury relevant for ALI/ ARDS. ${ }^{148,149}$

In contrast, animal models of indirect lung injury generally respond less well to surfactant administration. Injury from oleic acid infusion via the pulmonary artery shows almost no improvement with surfactant, ${ }^{150}$ although many would argue that this is a lethal injury with substantial cellular disruption ${ }^{151}$ that is unlikely to respond to any therapy. A porcine sepsis model that used intravenous li- popolysaccharide infusion showed some oxygenation improvement following surfactant administration, ${ }^{152,153}$ but the response was less striking than in the surfactant-treated animals injured with intratracheal lipopolysaccharide above. ${ }^{146,147}$ It is notable that the different responses to surfactant between direct and indirect lung injury in animals resemble the response pattern seen in humans; analysis of 2 trials found that direct pulmonary ALI/ARDS is impacted most beneficially by surfactant therapy. ${ }^{127,154}$

In addition to evaluating efficacy, animal models can also be very useful in evaluating other aspects of surfactant therapy, such as optimizing delivery protocols, doses, and the timing of therapy. Studies of this kind may be descriptive from a scientific perspective, but they can have great practical benefit in optimizing delivery, distribution, and dosing-related aspects of surfactant therapy. However, animal work to date has not been particularly extensive or systematic in investigating these phenomena. One delivery-related area that has received attention in animal studies involves surfactant aerosolization. Multiple studies have reported respiratory improvement with surfactant aerosol in animals with surfactant deficiency or dysfunction, ${ }^{131,135,153,155-163}$ although other aerosol studies have been less positive. ${ }^{164-167}$ Several animal studies have directly compared aerosolization to tracheal instillation, and reported that aerosolization can have equal or greater effectiveness, ${ }^{131,155,159}$ whereas others have found that instillation is more effective than aerosolization. ${ }^{131,165,168}$ An example illustrating the need for further clarity on this issue is the study by Lewis et al. ${ }^{131}$ In lung-lavaged sheep, exogenous bovine lung extract surfactant was effective when instilled but ineffective when aerosolized, whereas beractant in the same animal model was more effective when aerosolized than when instilled. Clinical studies with aerosolized surfactant have in general not had impressive results. A small pilot study by Jorch et al ${ }^{169}$ reported that aerosolized bovactant improved the alveolar-arterial oxygen difference in older pre-term infants (28-35 weeks gestation), but studies with other aerosolized surfactants in pre-term infants found no respiratory benefits, ${ }^{170-172}$ despite the known efficacy of instilled exogenous surfactant in that patient population. In addition, a large controlled study by Anzueto et al, ${ }^{64}$ in which they administered aerosolized colfosceril palmitate to adults with ALI/ARDS, was also negative, as discussed in more detail below.

If it is possible to perfect aerosol delivery technology for lung surfactants, this is clearly a conceptually attractive alternative to instillation for clinical application. Aerosol delivery might avoid the transient endotracheal tube (ETT) obstruction and resultant hypoxia and hypotension seen with bolus instillation. However, delivering aerosolized surfactant in sufficient quantity and making it distribute evenly throughout the alveoli of injured lungs is non-trivial. Aerosol enters only ventilated lung units. ${ }^{157,158,173}$ Aero- 
sol delivery to the alveoli in normal lungs is maximal in the particle-size range $0.5-2.0 \mu \mathrm{m}$, and it is possible to generate a stable surfactant aerosol with that particle size range from aqueous or powdered surfactant. ${ }^{135,174,175} \mathrm{~A}$ recent study by Ruppert et al ${ }^{135}$ demonstrated the ability to deliver substantial amounts of a powder recombinant protein $\mathrm{C}$ surfactant aerosol with a new aerosol generator to improve oxygenation and compliance in lung-lavaged rabbits. However, whether surfactant aerosolization can be accomplished in a sufficiently effective and efficient manner to replace instillation requires further and more detailed direct comparisons in animals and subsequently in human trials.

Animal studies have also investigated issues relevant to the preferred timing of surfactant therapy in ALI/ARDS. Bjorklund et al ${ }^{176}$ showed in lambs, and Hillman et al ${ }^{177}$ in sheep, that positive-pressure ventilation of the surfactantdeficient lung can result in substantial lung injury within minutes, which supports the view that early surfactant therapy is crucial. In addition, both animal ${ }^{178,179}$ and human studies ${ }^{180,181}$ have demonstrated that prophylactic administration of surfactant is more effective than later rescue surfactant delivery because of better surfactant distribution and avoidance of VILI. Whether the same is true in ALI/ ARDS is unknown, but by analogy it would seem likely that early surfactant treatment of ALI/ARDS would be more effective.

Other aspects of surfactant therapy that have been explored in animal studies include the volume and dose of surfactant, ${ }^{182}$ rapidity of administration, ${ }^{183}$ and method of respiratory support during surfactant administration. ${ }^{163,184}$ As a general rule, a larger instillation volume and/or higher dose results in more uniform distribution. ${ }^{182}$ Unfortunately, a larger instilled volume can also cause severe hypoxia and hypotension, due to transient ETT obstruction. ${ }^{154,185}$ The same trade-off is true for giving surfactant as a rapid bolus, as opposed to over a longer period; that is, a more homogeneous distribution is achieved with a rapid bolus, but this also risks obstructing the ETT. Using an alveolar recruitment maneuver (eg, manual bagging or a larger tidal volume) during instillation may facilitate surfactant distribution and reduce the degree or duration of hypoxia and hypotension. Studies by Krause et al ${ }^{136,137}$ in young rabbits and piglets with lung injury induced by in vivo lavage found that several methods of volume recruitment (increased ventilator peak inspiratory pressure, tidal volume, and/or PEEP) at the time of instillation significantly improved the pulmonary efficacy of surfactant therapy.

In summary, animal studies have helped to elucidate several aspects of surfactant efficacy and administration, and remain indispensible for investigating surfactant therapy and its optimization going forward. However, animal studies typically examine a relatively brief experimental timescale, and necessarily involve the use of non-human species. Questions of safety and clinical efficacy ultimately require studies with human patients.

\section{Human Studies}

A number of uncontrolled and controlled studies have documented clinical benefit from exogenous surfactant replacement therapy in term infants, children, and adults with acute respiratory failure (ALI/ARDS) 66-69,154,186-200 (Table 2). Of the 19 positive studies listed in Table 2, 9 were controlled trials ${ }^{67-69,154,192,197-200}$ and 10 were uncontrolled treatment trials, in which the risk of selection bias is inherent. An additional 4 positive case series found clinical improvement from surfactant therapy but are not included in Table 2. ${ }^{201-204}$ Figure 3 describes the clinical course of a representative child who received surfactant (calfactant) after near-drowning. ${ }^{205}$ Near-drowning washes out pulmonary surfactant and is often accompanied by hypoxia and aspiration of gastric contents, which may lead to permeability lung injury. Thus, it can involve both surfactant deficiency and dysfunction. Radiographic changes in lung aeration are clear and are reflected in the dramatic oxygenation improvement associated with calfactant administration.

Despite the relatively small size and mixed nature of the studies in Table 2, the sum of their findings shows that there are a number of specific indications where the evidence for the use and efficacy of exogenous surfactant therapy in acute pulmonary injury is compelling. One of the best-studied applications of surfactant therapy for an indication other than RDS is in full-term infants with meconium aspiration syndrome. ${ }^{66-69,196}$ Meconium is a thick, tarry mixture of bile acids and mucous glycoproteins that fills the fetal colon during gestation, and prenatal defecation and gasping episodes associated with maternal/fetal stress can lead to meconium aspiration at or prior to birth. Meconium mechanically obstructs airways, causes inflammation, ${ }^{206}$ and inhibits the biophysical activity of lung surfactant. ${ }^{97,207}$ Auten et al, ${ }^{196}$ Khammash et al, ${ }^{66}$ and Findlay et $\mathrm{al}^{67}$ have all reported significant lung-function improvement following exogenous surfactant administration (calfactant, beractant) to infants with meconium aspiration syndrome. The randomized controlled study by Findlay et al ${ }^{67}$ also found significant reductions in the incidence of pneumothorax, duration of mechanical ventilation and oxygen therapy, time of hospitalization, and extracorporeal membrane oxygenation (ECMO) requirement in 20 term infants with meconium aspiration syndrome treated with beractant, compared to a similar number of controls. Lotze et al ${ }^{68}$ also reported favorable results with beractant in a controlled trial in term infants referred for ECMO due to severe respiratory failure (meconium aspiration was a prev- 


\section{The Future of Exogenous Surfactant Therapy}

Table 2. Selected Controlled and Uncontrolled Clinical Studies That Reported Significant Benefits From Exogenous Surfactant Therapy in ALI/ ARDS

\begin{tabular}{|c|c|c|c|c|c|}
\hline $\begin{array}{l}\text { First } \\
\text { Author }\end{array}$ & $\begin{array}{l}\text { Patient } \\
\text { Type }\end{array}$ & $\begin{array}{l}\text { Number of } \\
\text { Patients }\end{array}$ & Disease & Surfactant & Outcomes \\
\hline Günther ${ }^{186}$ & Adults & 27 & ARDS & Bovactant & Improved surfactant function \\
\hline Walmrath $^{188}$ & Adults & 10 & ARDS, sepsis & Bovactant & Improved oxygenation \\
\hline Spragg $^{189}$ & Adults & 6 & ARDS, multiple causes & Poractantalfa & $\begin{array}{l}\text { Improved oxygenation and biophysical } \\
\text { function }\end{array}$ \\
\hline Wiswell $^{190}$ & Adults & 12 & ARDS, multiple causes & Lucinactant & Improved oxygenation \\
\hline Amital $^{200}$ & Adults & 42 & Lung transplant & Calfactant & $\begin{array}{l}\text { Improved oxygenation, better graft } \\
\text { function }\end{array}$ \\
\hline Willson $^{191,192^{*}}$ & Children & 29 and 42 & ARDS, multiple causes & Calfactant & Improved oxygenation \\
\hline Willson $^{154}$ & Children & 152 & ARDS, multiple causes & Calfactant & Improved survival and ventilation \\
\hline López-Herce ${ }^{193}$ & Children & 20 & ARDS + after cardiac surgery & Poractantalfa & Improved oxygenation \\
\hline Hermon $^{194}$ & Children & 19 & ARDS + after cardiac surgery & $\begin{array}{l}\text { Poractant alfa or } \\
\text { bovactant }\end{array}$ & Improved oxygenation \\
\hline Herting ${ }^{195}$ & Children & 8 & Pneumonia & Poractantalfa & Improved oxygenation \\
\hline Moller $^{199}$ & Children & 35 & ARDS, multiple causes & Bovactant & Improved oxygenation \\
\hline Auten $^{196}$ & Infants & 14 & $\begin{array}{l}\text { Meconium aspiration syndrome } \\
\text { or pneumonia }\end{array}$ & $\begin{array}{r}\text { Calfactant (calf lung } \\
\text { surfactant extract) }\end{array}$ & Improved oxygenation \\
\hline Lotze $^{68,69}$ & Infants & 28 and 328 & ECMO, multiple indications & Beractant & $\begin{array}{l}\text { Improved oxygenation, decreased use of } \\
\text { ECMO }\end{array}$ \\
\hline Khammash $^{66}$ & Infants & 20 & Meconium aspiration syndrome & $\begin{array}{l}\text { Bovine lung extract } \\
\text { surfactant }\end{array}$ & Improved in $75 \%$ of patients \\
\hline Findlay $^{67}$ & Infants & 40 & Meconium aspiration syndrome & Beractant & $\begin{array}{l}\text { Improved oxygenation, less pneumothorax } \\
\text { and mechanical ventilation }\end{array}$ \\
\hline Luchetti $^{197,198}$ & Infants & 20 and 40 & $\begin{array}{l}\text { Respiratory syncytial virus } \\
\text { bronchiolitis }\end{array}$ & Poractantalfa & Improved oxygenation \\
\hline \multicolumn{6}{|c|}{$\begin{array}{l}\text { The tabulated studies by Willson et al, }{ }^{154,192} \text { Fin } \\
\text { uncontrolled treatment trials. Four case series }{ }^{201-20} \\
\text { ALI = acute lung injury } \\
\text { ARDS = acute respiratory distress syndrome } \\
\text { ECMO = extracorporeal membrane oxygenation } \\
\text { (Data from Reference } 16 . \text { ) }\end{array}$} \\
\hline
\end{tabular}

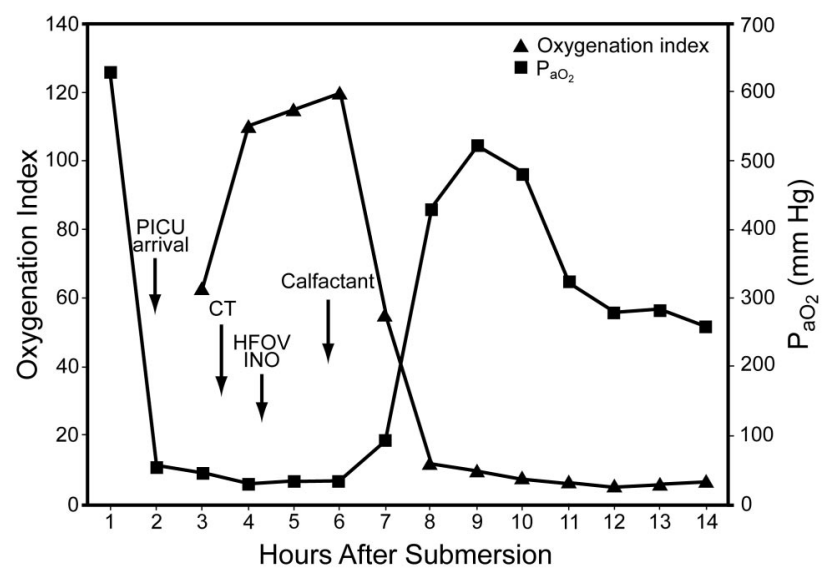

Fig. 3. Clinical course of a child before and after calfactant administration. HFOV $=$ high-frequency oscillatory ventilation. INO = inhaled nitric oxide. CT = chest tube. (Adapted from Reference 205.)

alent diagnosis). A subsequent larger multicenter controlled trial with 328 term infants similarly reported significant improvements in respiratory status and decreased need for
ECMO following surfactant treatment. ${ }^{69}$ Exogenous surfactant is now routinely used in many institutions to treat neonates with meconium aspiration syndrome, as well as infants with respiratory failure from pneumonia. Clinical studies documenting the efficacy of surfactant therapy in pneumonia are less extensive than for meconium aspiration syndrome, but those that are available have been positive. ${ }^{196-198}$ An initial uncontrolled study by Auten et al ${ }^{196}$ reported significant improvements in oxygenation in term infants with pneumonia following instillation of calfactant (calf lung surfactant extract [CLSE]). Also, Luchetti et al ${ }^{197,198}$ reported both improved oxygenation and shortened duration of ventilation following treatment with porcine surfactant (poractant alfa, $50 \mathrm{mg} / \mathrm{kg}$ ) in 2 small controlled but unblinded studies of infants with RSV bronchiolitis.

Experience with clinical surfactant therapy in adults with ALI/ARDS has been much less encouraging than in younger patients. In a large controlled trial, Anzueto et al ${ }^{64}$ administered nebulized colfosceril palmitate or placebo to 725 
adults with ARDS secondary to sepsis and found no oxygenation improvement and no effect on morbidity or mortality. However, that study was flawed by the facts that colfosceril palmitate is a poor surfactant, and the aerosol technology they used delivered very little colfosceril palmitate to the alveoli. Additionally, it appears now, from both animal and human data, that surfactant therapy is inherently less effective in indirect lung injury such as sepsis, compared to direct pulmonary ALI/ARDS. Several other controlled clinical trials of surfactant therapy in adults have also reported disappointing results. Gregory et al ${ }^{65}$ found some oxygenation improvement for a subgroup of patients with sepsis-induced ALI/ARDS who received intermediate-size doses of beractant $(100 \mathrm{mg} / \mathrm{kg})$, but no oxygenation improvement in other treated groups, and no long-term benefits in the overall 43 surfactant-treated patients studied.

Spragg et al, ${ }^{127}$ using synthetic SP-C surfactant (recombinant protein $\mathrm{C}$ surfactant), also reported improved oxygenation but no long-term benefits, relative to placebo, in adults with ARDS. On post hoc analysis, however, surfactant-treated subjects with direct lung injury appeared to have better survival, so Spragg et al carried out a similarly designed randomized controlled trial focused on direct lung injury. Unfortunately, that study was stopped for futility after an interim analysis at 800 subjects (personal communication, Roger Spragg, Division of Pulmonary and Critical Care Medicine, University of California School of Medicine, San Diego, California, 2010). Finally, a study by Kesecioglu et al, ${ }^{185}$ with a porcine surfactant called HL-10, was also stopped at an interim analysis because of a potential harmful effect. They instilled surfactant in 2 large boluses and saw a significant incidence of peri-dosing hypoxia and hypotension $(>60 \%)$. There was also a suggestion of higher mortality in the surfactant group at the 6-month follow-up, which was not seen at 3 months, although there is no known plausible mechanism for that higher mortality.

Exogenous surfactant therapy was successfully used in a randomized controlled study by Amital et al,200 in 42 adult patients following lung transplant. The calfactanttreated patients had better oxygenation, less post-graft dysfunction, shorter ICU stay, and better lung function at one month. That study followed multiple uncontrolled case studies that also reported clinical improvements from exogenous surfactant therapy in adults and children after lung transplantation. ${ }^{201-203}$

Controlled studies of surfactant therapy in children with ALI/ARDS have been more encouraging than those in adults. A randomized but unblinded trial by Willson et al ${ }^{192}$ in 42 children with ALI/ARDS found that those who received calfactant $(70 \mathrm{mg} / \mathrm{kg}$ ) had immediate improvement in oxygenation and fewer ventilator days and days in intensive care. That trial followed an initial uncontrolled treatment study by the same group, which found improved oxygenation in 24 children (ages 0.1-16 y) with ALI/ ARDS treated with instilled calfactant. ${ }^{191}$

A controlled study by Moller et al ${ }^{199}$ also reported that children with ARDS showed immediate oxygenation improvement and less need for rescue therapy following treatment with beractant, but the trial was underpowered to assess more definitive longer-term outcomes. A larger and more recent blinded controlled study in 2005 by Willson et al, ${ }^{154}$ in patients up to age 21 years with ALI/ARDS, found that treatment with calfactant, relative to placebo, was associated with immediate oxygenation benefit and a significant survival advantage (Table 3 ). In a post hoc analysis, the benefits of surfactant therapy were confined to the 98-patient subgroup with direct pulmonary ALI/ ARDS (Table 4), which prompted a larger prospective trial in both adults and children with direct lung injury: the Calfactant for Direct Acute Respiratory Distress Syndrome (CARDS) trial (http://clinicaltrials.gov/ct2/show/ NCT00682500), which was a prospective, masked randomized controlled trial of calfactant versus placebo. The study was carried out in more than 30 centers in the United States, Canada, Korea, Israel, Australia, and New Zealand. The data analysis is incomplete, but, unfortunately, both the adult and pediatric arms were stopped because of futility. The reasons for the failure of this trial after the success of the previous trials of Willson et al ${ }^{154,192}$ remain to be elucidated.

\section{Summary and the Future of Surfactant Therapy}

Exogenous surfactant has a well established place in the prevention and treatment of infant RDS. Efficacy in other types of ALI in neonates (eg, meconium aspiration, neonatal pneumonia) has also been studied in controlled and uncontrolled trials, and surfactant treatment for those conditions has become fairly routine. In lung injury beyond the neonatal period, however, evidence for the efficacy of surfactant therapy is less extensive, although several controlled studies in children and older adolescents with ALI/ ARDS have been encouraging. ${ }^{154,192}$ Evidence for surfactant therapy in adults with ALI/ARDS is much less compelling, and remains a work in progress.

Many factors can contribute to inconsistency in the results about surfactant therapy in ALI/ARDS. The complexity of ALI/ARDS itself undoubtedly plays a large role, as it is not a single disease but, rather, the end result of many different types of acute pulmonary injury. The more favorable response in patients with direct versus indirect lung injury found by Spragg et al ${ }^{127}$ and Willson et al ${ }^{154}$ illustrates this point. Timing of surfactant administration in ALI/ARDS may also be very important for efficacy, particularly if a major benefit of the therapy is to prevent 
Table 3. Clinical Outcomes in the 2005 Study by Willson et $\mathrm{al}^{154}$

\begin{tabular}{|c|c|c|c|}
\hline & $\begin{array}{l}\text { Calfactant } \\
(\text { no. }=75)\end{array}$ & $\begin{array}{c}\text { Placebo } \\
(\text { no. }=75)\end{array}$ & $P$ \\
\hline \multicolumn{4}{|l|}{ Mortality, no. (\%) } \\
\hline Died (in hospital) & $15(19)$ & $27(36)$ & .03 \\
\hline Died without extubation & $12(16)$ & $24(32)$ & .02 \\
\hline Failed conventional mechanical ventilation, no. $(\%)^{*}$ & $13(21)$ & $26(42)$ & .02 \\
\hline ECMO, no. & 3 & 3 & .99 \\
\hline Nitric oxide, no. & 9 & 10 & .80 \\
\hline HFOV after entry, no. & 7 & 15 & .07 \\
\hline \multicolumn{4}{|l|}{ Secondary Outcomes (mean \pm SD) } \\
\hline PICU stay (d) & $15.2 \pm 13.3$ & $13.6 \pm 11.6$ & .85 \\
\hline Hospital stay (d) & $26.8 \pm 26$ & $25.3 \pm 32.2$ & .91 \\
\hline Days $\mathrm{O}_{2}$ therapy (d) & $17.3 \pm 16$ & $18.5 \pm 31$ & .93 \\
\hline Hospital charges $(\$)$ & & & .83 \\
\hline Total & $205,000 \pm 220,000$ & $213,000 \pm 226,000$ & .74 \\
\hline Per day & $7,500 \pm 7,600$ & $7,900 \pm 7,500$ & \\
\hline
\end{tabular}

Table 4. Efficacy of Exogenous Surfactant in Direct and Indirect Lung Injury in the Controlled 2005 Study by Willson et $\mathrm{al}^{154}$ in Patients Up To 21 Years Old With ALI/ARDS

\begin{tabular}{|c|c|c|c|}
\hline & Placebo & Calfactant* & $P$ \\
\hline Direct lung injury, no. & 48 & 50 & NA \\
\hline $\begin{array}{l}\text { Oxygenation index decrease } \\
\quad \geq 25 \%(\%)\end{array}$ & 31 & 66 & $<.001$ \\
\hline Ventilator days & $17 \pm 10$ & $13 \pm 9$ & .05 \\
\hline Died $(\%)$ & 38 & 8 & $<.001$ \\
\hline Indirect lung injury, no. & 27 & 27 & NA \\
\hline $\begin{array}{l}\text { Oxygenation index decrease } \\
\quad \geq 25 \%(\%)\end{array}$ & 41 & 37 & .79 \\
\hline Ventilator days & $17 \pm 10$ & $18 \pm 10$ & .75 \\
\hline Died $(\%)$ & 33 & 41 & .65 \\
\hline $\begin{array}{l} \pm \text { values are mean } \pm \mathrm{SD} \\
* \text { Calfactant dose was } 70 \mathrm{mg} / \mathrm{kg} \text { body wei } \\
\text { index decrease of } \geq 25 \% \text {, days on mecha } \\
\text { calculated in a post-hoc analysis. } \\
\mathrm{NA}=\text { not applicable } \\
\mathrm{ALI}=\text { acute lung injury } \\
\mathrm{ARDS}=\text { acute respiratory distress syndro } \\
\mathrm{ECMO}=\text { extracorporeal membrane oxyg }\end{array}$ & $\begin{array}{l}{ }^{4} \text { Percentages } \\
\text { ventilation, a }\end{array}$ & $\begin{array}{l}\text { of patients with a } \\
\text { d percentage mor }\end{array}$ & $\begin{array}{l}\text { ygenation } \\
\text { were }\end{array}$ \\
\hline
\end{tabular}

or ameliorate VILI, which would require early use of surfactant.

The effectiveness of surfactant delivery due to differences in drug volume, drug viscosity, delivery rate, or delivery method (instillation vs aerosolization) may also be of great importance for surfactant therapy in ALI/ARDS. Pulmonary pathology in inflammatory injury is severe and heterogeneous, ${ }^{208-211}$ and getting exogenous surfactant into injured lung areas in a concentration sufficient to over- come inhibition by inflammatory and other substances is a challenge. How the lung is ventilated during and immediately after surfactant delivery can substantially impact drug distribution. The recruitment of alveoli by bagging or other recruitment maneuvers during surfactant drug delivery may open otherwise inaccessible areas of injured lung, and these may then remain open if exogenous surfactant has reached them effectively. ${ }^{136,137}$ Also, if surfactant delivery via aerosolization can be perfected, it might avoid the transient hypoxia, hypertension, and ETT obstruction associated with instillation. However, studies have shown that, despite the drawbacks, instillation benefits patients with several forms of ARDS.

Another major variable in surfactant therapy is the specific composition and activity of the exogenous surfactant drug used. A large number of studies have identified significant differences in activity between surfactant drugs at the laboratory level.5,16,18,72 Differences in exogenous surfactant activity are likely to be more crucial in treating ALI/ARDS, compared to RDS. Successful treatment of ALI/ARDS requires the most robust surfactants because of the need to resist inhibition by substances that leak into the alveolar space as a result of permeability injury. In general, surfactants with an adequate percentage of SP-B appear to be the most resistant to inhibition. It is promising that new synthetic surfactants based on active SP-B peptides are currently being developed, including super mini-B surfactant. ${ }^{22}$ New synthetic lung surfactants under development can also be formulated to contain novel active lipids that resist degradation by phospholipases in injured lungs. ${ }^{19,23,48}$ 
A final factor not emphasized in this article is the potential of combination therapies in ALI/ARDS. The pathophysiology of ALI/ARDS is complex and multifaceted, and single agents may not be sufficient to achieve the most substantial benefits to long-term patient outcomes. The use of exogenous surfactant in conjunction with other modalities to simultaneously attack different aspects of the pathophysiology of ALI/ARDS may prove to be synergisticnot unlike the use of combination chemotherapy for various types of cancer. As one example, if surfactant can improve the distribution of ventilation in the lung, simultaneous use of nitric oxide as a synergistic agent may increase perfusion to the newly ventilated lung units. The potential use of other pharmacologic agents, along with gentle lowtidal-volume ventilation and careful fluid management, in combination with surfactant is also possible. Detailed discussion of combination therapy approaches for ALI/ARDS are reviewed elsewhere. ${ }^{18,212}$

In summary, it is likely that surfactant will find a place in our armamentarium for the treatment of ALI/ARDS when some of the above issues are clarified. As the famous philosopher Yogi Berra so eloquently stated, "Predictions are difficult, particularly about the future." Nonetheless, surfactant therapy has in fact already been shown to be beneficial in several lung-injury applications in term infants and children, in addition to its life-saving use in pre-term infants with RDS. The jury is still out with respect to the use of surfactant therapy in adults with ALI/ ARDS, and several negative studies clearly do exist. However, the perspective of history shows that the first trials of surfactant therapy in RDS were unsuccessful due to the use of ineffective surfactants and delivery methods, and it was more than 2 decades after surfactant deficiency was first suggested to be the cause of $\mathrm{RDS}^{7}$ before Fujiwara et $\mathrm{a}^{13}$ demonstrated successful treatment of premature infants with exogenous surfactant. Lung injuries leading to clinical ALI/ARDS clearly comprise a more complicated and diverse set of conditions than RDS, and finding the most successful surfactant interventions, delivery methods, and possible synergistic combination therapies may simply require more time.

\section{REFERENCES}

1. von Neergaard K. Neue auffassungen uber einen grundbegriff der atemmechanik. Dieretraktionskraft der lunge, abhangig von der oberflachenspannung in den alveolen. Z Ges Exp Med 1929;66:373394. Article in German.

2. Pattle RE. Properties, function, and origin of the alveolar lining layer. Nature 1955;175(4469):1125-1126.

3. Pattle RE. Properties, function and origin of the alveolar lining layer. Proc R Soc (Lond) Ser B 1958;148(931):217-240.

4. Clements JA. Surface tension of lung extracts. Proc Soc Exp Biol Med 1957;95(1):170-172.

5. Notter RH. Lung surfactants: basic science and clinical applications. New York: Marcel Dekker; 2000.
6. Notter RH, Finkelstein JN. Pulmonary surfactant: an interdisciplinary approach. J Appl Physiol 1984;57(6):1613-1624.

7. Avery ME, Mead J. Surface properties in relation to atelectasis and hyaline membrane disease. Am J Dis Child 1959;97(5 Pt 1):517523.

8. Robillard E, Alarie Y, Dagenais-Perusse P, Baril E, Guilbeault A. Microaerosol administration of synthetic $\beta, \gamma$-dipalmitoyl-L- $\alpha$-lecithin in the respiratory distress syndrome: a preliminary report. Can Med Assoc J 1964;90:55-57.

9. Chu J, Clements JA, Cotton EK, Klaus MH, Sweet AY, Thomas MA, et al. The pulmonary hypoperfusion syndrome. Pediatrics 1965; 35:733-742.

10. Chu J, Clements JA, Cotton EK, Klaus MH, Sweet AY, Tooley WH. Neonatal pulmonary ischemia. Clinical and physiologic studies. Pediatrics 1967;40(4):709-782.

11. Enhorning G, Grossman G, Robertson B. Pharyngeal deposition of surfactant in the premature rabbit fetus. Biol Neonate 1973;22:126132.

12. Enhorning G, Grossman G, Robertson B. Tracheal deposition of surfactant before the first breath. Am Rev Respir Dis 1973;107(6): 921-927.

13. Fujiwara T, Maeta H, Chida S, Morita T, Watabe Y, Abe T. Artificial surfactant therapy in hyaline membrane disease. Lancet 1980; 1(8159):55-59.

14. Jobe AH. Pulmonary surfactant therapy. N Engl J Med 1993;328(12): 861-868.

15. Soll RF. Surfactant therapy in the USA: trials and current routines. Biol Neonate 1997;71(Suppl 1):1-7.

16. Willson DF, Chess PR, Notter RH. Surfactant for pediatric acute lung injury. Pediatr Clin N Am 2008;55(3):545-575.

17. Willson DF, Chess PR, Wang Z, Notter RH. Pulmonary surfactant: biology and therapy. In: Wheeler DA WH, Shanley TA, editors. Pediatric critical care medicine: basic science and clinical evidence. London: Springer-Verlag; 2007:453-466.

18. Raghavendran K, Pryhuber GS, Chess PR, BAD, Knight PR, Notter RH. Pharmacotherapy of acute lung injury and acute respiratory distress syndrome. Curr Med Chem 2008;15(19):1911-1924.

19. Notter RH, Schwan AL, Wang Z, Waring AJ. Novel phospholipase-resistant lipid/peptide synthetic lung surfactants. Mini-Rev Med Chem 2007;7(9):932-944.

20. Walther FJ, Waring AJ, Sherman MA, Zasadzinski J, Gordon LM. Hydrophobic surfactant proteins and their analogues. Neonatology 2007;91(4):303-310.

21. Walther FJ, Waring AJ, Hernandez-Juviel JM, Gordon LM, Schwan AL, Jung CL, et al. Dynamic surface activity of a fully-synthetic phospholipase-resistant lipid/peptide lung surfactant. PLoS ONE 2007;2(10):e1039. DOI: 1010.1371/journal.pone.0001039.

22. Walther FJ, Waring AJ, Hernandez-Juviel JM, Gordon LM, Wang Z, Jung CL, et al. Critical structural and functional roles for the $\mathrm{N}$-terminal insertion sequence in surfactant protein B analogs. PLoS ONE 2010;5(1):e8672. doi:8610.1371/journal.pone.0008672.

23. Wang Z, Chang Y, Schwan AL, Notter RH. Activity and inhibition resistance of a phospholipase-resistant synthetic exogenous surfactant in excised rat lungs. Am J Respir Cell Mol Biol 2007;37(4): 387-394.

24. Mingarro I, Lukovic D, Vilar M, Pérez-Gil J. Synthetic pulmonary surfactant preparations: new developments and future trends. Current Med Chem 2008;15(4):303-403.

25. Chess P, Finkelstein JN, Holm BA, Notter RH. Surfactant replacement therapy in lung injury. In: Notter RH, Finkelstein JN, Holm BA, editors. Lung injury: mechanisms, pathophysiology, and therapy. Boca Raton: Taylor \& Francis; 2005:617-663. 


\section{The Future of Exogenous Surfactant Therapy}

26. Mizuno K, Ikegami M, Chen C-M, Ueda T, Jobe AH. Surfactant protein-B supplementation improves in vivo function of a modified natural surfactant. Pediatr Res 1995;37(3):271-276.

27. Seeger W, Grube C, Günther A, Schmidt R. Surfactant inhibition by plasma proteins: differential sensitivity of various surfactant preparations. Eur Respir J 1993;6(7):971-977.

28. Hamvas A, Cole FS, deMello DE, Moxley M, Whitsett JA, Colten HR, et al. Surfactant protein B deficiency: antenatal diagnosis and prospective treatment with surfactant replacement. J Pediatr 1994; 125(3):356-361.

29. Notter RH, Wang Z, Egan EA, Holm BA. Component-specific surface and physiological activity in bovine-derived lung surfactants. Chem Phys Lipids 2002;114(1):21-34.

30. Curstedt T, Jornvall H, Robertson B, Bergman T, Berggren P. Two hydrophobic low-molecular-mass protein fractions of pulmonary surfactant: characterization and biophysical activity. Eur J Biochem 1987;168(2):255-262.

31. Oosterlaken-Dijksterhuis MA, Haagsman HP, van Golde LM, Demel RA. Characterization of lipid insertion into monomolecular layers mediated by lung surfactant proteins SP-B and SP-C. Biochemistry 1991;30(45):10965-10971.

32. Oosterlaken-Dijksterhuis MA, Haagsman HP, van Golde LM, Demel RA. Interaction of lipid vesicles with monomolecular layers containing lung surfactant proteins SP-B or SP-C. Biochemistry 1991;30(33):8276-8281.

33. Oosterlaken-Dijksterhuis MA, van Eijk M, van Golde LMG, Haagsman HP. Lipid mixing is mediated by the hydrophobic surfactant protein SP-B but not by SP-C. Biochim Biophys Acta 1992;1110(1): 45-50.

34. Revak SD, Merritt TA, Degryse E, Stefani L, Courtney M, Hallman $\mathrm{M}$, et al. The use of human low molecular weight (LMW) apoproteins in the reconstitution of surfactant biological activity. J Clin Invest 1988;81(3):826-833.

35. Seeger W, Günther A, Thede C. Differential sensitivity to fibrinogen inhibition of SP-C- vs. SP-B-based surfactants Am J Physiol 1992;261(3 Pt 1):L286-L291.

36. Wang Z, Gurel O, Baatz JE, Notter RH. Differential activity and lack of synergy of lung surfactant proteins SP-B and SP-C in surface-active interactions with phospholipids. J Lipid Res 1996;37(8): 1749-1760.

37. Yu SH, Possmayer F. Comparative studies on the biophysical activities of the low-molecular-weight hydrophobic proteins purified from bovine pulmonary surfactant. Biochim Biophys Acta 1988; 961(3):337-350.

38. Wang Z, Baatz JE, Holm BA, Notter RH. Content-dependent activity of lung surfactant protein B (SP-B) in mixtures with lipids. Am J Physiol 2002;283(5):L897-L906.

39. Walther FJ, Hernandez-Juviel J, Bruni R, Waring A. Spiking Survanta with synthetic surfactant peptides improves oxygenation in surfactant-deficient rats. Am J Respir Crit Care Med 1997;156(3 Pt 1):855-861.

40. Clark JC, Weaver TE, Iwamoto HS, Ikegami M, Jobe AH, Hull $\mathrm{WM}$, et al. Decreased lung compliance and air trapping in heterozygous SP-B-deficient mice. Am J Respir Cell Mol Biol 1997;16(1): 46-52.

41. Hamvas A, Nogee LM, deMello DE, Cole FS. Pathophysiology and treatment of surfactant protein-B deficiency. Biol Neonate 1995; 67(Suppl 1):18-31.

42. Hamvas A, Nogee LM, Mallory GB, Spray TL, Huddleston CB, August A, et al. Lung transplantation for treatment of infants with surfactant protein B deficiency. J Pediatr 1997;130(2):231-239.

43. Whitsett JA, Nogee LM, Weaver TE, Horowitz AD. Human surfactant protein B structure, function, regulation, and genetic disease. Physiol Rev 1995;75(4):749-757.
44. Ikegami M, Whitsett JA, Martis PC, Weaver TE. Reversibility of lung inflammation caused by SP-B deficiency. Am J Physiol Lung Cell Mol Physiol 2005;289(6):L962-L970.

45. Curstedt T, Johansson J. New synthetic surfactant: how and when? Biol Neonate 2006;89(4):336-339.

46. Turcotte JG, Sacco AM, Steim JM, Tabak SA, Notter RH. Chemical synthesis and surface properties of an analog of the pulmonary surfactant dipalmitoyl phosphatidylcholine analog. Biochim Biophys Acta 1977;488(2):235-248.

47. Turcotte JG, Lin WH, Pivarnik PE, Sacco AM, Bermel MS, Lu Z, et al. Chemical synthesis and surface activity of lung surfactant phospholipid analogs. II. Racemic N-substituted diether phosphonolipids. Biochim Biophys Acta 1991;1084(1):1-12.

48. Wang Z, Schwan AL, Lairson LL, O’Donnell JS, Byrne GF, Foye A, et al. Surface activity of a synthetic lung surfactant containing a phospholipase-resistant phosphonolipid analog of dipalmitoyl phosphatidylcholine. Am J Physiol 2003;285(3):L550-L559.

49. Notter RH, Wang Z, Wang Z, Davy J, Schwan AL. Synthesis and surface activity of diether-linked phosphoglycerols: potential applications for exogenous lung surfactants. Bioorg Med Chem Lett 2007;17(1):113-117.

50. Chang Y, Wang Z, Schwan AL, Wang Z, Holm BA, Baatz JE, et al. Surface properties of sulfur- and ether-linked phosphonolipids with and without purified hydrophobic lung surfactant proteins. Chem Phys Lipids 2005;137(1-2):77-93.

51. Kim DK, Fukuda T, Thompson BT, Cockrill B, Hales C, Bonventre JV. Bronchoalveolar lavage fluid phospholipase $\mathrm{A}_{2}$ activities are increased in human adult respiratory distress syndrome. Am J Physiol 1995;269(1 Pt 1):L109-L118.

52. Touqui L, Arbibe L. A role for phospholipase $\mathrm{A}_{2}$ in ARDS pathogenesis. Molec Med Today 1999;5(6):244-249.

53. Vadas P. Elevated plasma phospholipase $\mathrm{A}_{2}$ levels: correlation with the hemodynamic and pulmonary changes in Gram-negative septic shock. J Lab Clin Med 1984;104(6):873-881.

54. Vadas P, Pruzanski W. Role of secretory phospholipases $A_{2}$ in the pathobiology of disease. Lab Invest 1986;55(4):391-404.

55. Ackerman SJ, Kwatia MA, Doyle CB, Enhorning G. Hydrolysis of surfactant phospholipids catalyzed by phospholipase $\mathrm{A}_{2}$ and eosinophil lysophospholipases causes surfactant dysfunction: a mechanism for small airway closure in asthma. Chest 2003;123(3 Suppl): 255S.

56. Attalah HL, Wu Y, Alaoui-El-Azher M, Thouron F, Koumanov K, Wolf $\mathrm{C}$, et al. Induction of type-IIA secretory phospholipase $\mathrm{A}_{2}$ in animal models of acute lung injury. Eur Respir J 2003;21(6):10401045.

57. Nakos G, Kitsiouli E, Hatzidaki E, Koulouras V, Touqui L, Lekka ME. Phospholipases $\mathrm{A}_{2}$ and platelet-activating-factor acetylhydrolase in patients with acute respiratory distress syndrome. Crit Care Med 2005;33(4):772-779.

58. Bose C, Corbet A, Bose G, Garcia-Prats J, Lombardy L, Wold D, et al. Improved outcome at 28 days of age for very low birth weight infants treated with a single dose of a synthetic surfactant. J Pediatr 1990;117(6):947-953.

59. Corbet A, Bucciarelli R, Goldman S, Mammel M, Wold D, Long W. Decreased mortality rate among small premature infants treated at birth with a single dose of synthetic surfactant: a multicenter controlled trial. J Pediatr 1991;118(2):595-605.

60. Long W, Corbet A, Cotton R, Courtney S, McGuiness G, Walter D, et al. A controlled trial of synthetic surfactant in infants weighing 1,250 g or more with respiratory distress syndrome. N Engl J Med 1991;325(24):1696-1703.

61. Long W, Thompson R, Sundell H, Schumacher R, Volberg F, Guthrie R. Effects of two rescue doses of a synthetic surfactant on mortality rate and survival without bronchopulmonary dysplasia in 


\section{The Future of Exogenous Surfactant Therapy}

700 to 1350 gram infants with respiratory distress syndrome. J Pediatr 1991;11(4 Pt 1):595-605.

62. Hudak ML, Farrell EE, Rosenberg AA, Jung AL, Auten RL, Durand DJ, et al. A multicenter randomized masked comparison of natural vs synthetic surfactant for the treatment of respiratory distress syndrome. J Pediatr 1996;128(3):396-406.

63. Hudak ML, Martin DJ, Egan EA, Matteson EJ, Cummings J, Jung AL, et al. A multicenter randomized masked comparison trial of synthetic surfactant versus calf lung surfactant extract in the prevention of neonatal respiratory distress syndrome. Pediatrics 1997; 100(1):39-50.

64. Anzueto A, Baughman RP, Guntupalli KK, Weg JG, Wiedemann HP, Raventos AA, et al. Aerosolized surfactant in adults with sepsis-induced acute respiratory distress syndrome. N Engl J Med 1996;334(22):1417-1421.

65. Gregory TJ, Steinberg KP, Spragg R, Gadek JE, Hyers TM, Longmere WJ, et al. Bovine surfactant therapy for patients with acute respiratory distress syndrome. Am J Respir Crit Care Med 1997; 155(4):109-131.

66. Khammash H, Perlman M, Wojtulewicz J, Dunn M. Surfactant therapy in full-term neonates with severe respiratory failure. Pediatrics 1993;92(1):135-139.

67. Findlay RD, Taeusch HW, Walther FJ. Surfactant replacement therapy for meconium aspiration syndrome. Pediatrics 1996;97(1):4852

68. Lotze A, Knight GR, Martin GR, Bulas DI, Hull WM, O'Donnell RM, et al. Improved pulmonary outcome after exogenous surfactant therapy for respiratory failure in term infants requiring extracorporeal membrane oxygenation. J Pediatr 1993;122(2):261-268.

69. Lotze A, Mitchell BR, Bulas DI, Zola EM, Shalwitz RA, Gunkel JH. Multicenter study of surfactant (beractant) use in the treatment of term infants with severe respiratory failure. J Pediatr 1998;132(1): 40-47.

70. Jobe AH, Ikegami M. Surfactant and acute lung injury. Proc Assoc Am Physiol 1998;110(6):489-495.

71. Notter RH, Wang Z. Pulmonary surfactant: physical chemistry, physiology and replacement. Rev Chem Eng 1997;13:1-118.

72. Wang Z, Holm BA, Matalon S, Notter RH. Surfactant activity and dysfunction in lung injury. In: Notter RH, Finkelstein JN, Holm BA, editors. Lung injury: mechanisms, pathophysiology, and therapy. Boca Raton: Taylor \& Francis; 2005;297-352.

73. Holm BA, Notter RH, Finkelstein JH. Surface property changes from interactions of albumin with natural lung surfactant and extracted lung lipids. Chem Phys Lipids 1985;38(3):287-298.

74. Seeger W, Stöhr G, Wolf HR, Neuhof H. Alteration of surfactant function due to protein leakage: special interaction with fibrin monomer. J Appl Physiol 1985;58(2):326-338.

75. Holm BA, Notter RH. Effects of hemoglobin and cell membrane lipids on pulmonary surfactant activity. J Appl Physiol 1987;63(4): 1434-1442.

76. Holm BA, Enhorning G, Notter RH. A biophysical mechanism by which plasma proteins inhibit lung surfactant activity. Chem Phys Lipids 1988;49(1-2):49-55.

77. Fuchimukai T, Fujiwara T, Takahashi A, Enhorning G. Artificial pulmonary surfactant inhibited by proteins. J Appl Physiol 1987; 62(2):429-437.

78. Keough KWM, Parsons CS, Tweeddale MG. Interactions between plasma proteins and pulmonary surfactant: pulsating bubble studies. Can J Physiol Pharmacol 1989;67(6):663-668.

79. Wang Z, Notter RH. Additivity of protein and non-protein inhibitors of lung surfactant activity. Am J Respir Crit Care Med 1998; 158(1):28-35.
80. Hall SB, Hyde RW, Notter RH. Changes in subphase surfactant aggregates in rabbits injured by free fatty acid. Am J Respir Crit Care Med 1994;149(5):1099-1106.

81. Hall SB, Lu ZR, Venkitaraman AR, Hyde RW, Notter RH. Inhibition of pulmonary surfactant by oleic acid: mechanisms and characteristics. J Appl Physiol 1992;72:1708-1716.

82. Hall SB, Notter RH, Smith RJ, Hyde RW. Altered function of pulmonary surfactant in fatty acid lung injury. J Appl Physiol 1990; 69(3):1143-1149.

83. Holm BA, Wang Z, Notter RH. Multiple mechanisms of lung surfactant inhibition. Pediatr Res 1999;46(1):85-93.

84. Seeger W, Lepper H, Hellmut RD, Neuhof H. Alteration of alveolar surfactant function after exposure to oxidant stress and to oxygenated and native arachadonic acid in vitro. Biochim Biophys Acta 1985;835(1):58-67.

85. Davidson BA, Knight PR, Wang Z, Chess PR, Holm BA, Russo TA, et al. Surfactant alterations in acute inflammatory lung injury from aspiration of acid and gastric particulates. Am J Physiol Lung Cell Mol Physiol 2005;288(4):L699-L708.

86. Russo TA, Bartholomew LA, Davidson BA, Helinski JD, Carlino UB, Knight PR, et al. Total extracellular surfactant is increased but abnormal in a rat model of Gram-negative bacterial pneumonitis. Am J Physiol 2002;283(3):L655-L663.

87. Russo TA, Wang Z, Davidson BA, Genagon SA, Beanan JM, Olsen $\mathrm{R}$, et al. Surfactant dysfunction and lung injury due to the $E$. coli virulence factor hemolysin in a rat pneumonia model. Am J Physiol Lung Cell Mol Physiol 2007;292(3):L632-L643.

88. Wright TW, Notter RH, Wang Z, Harmsen AG, Gigliotti F. Pulmonary inflammation disrupts surfactant function during Pneumocystis carinii pneumonia. Infect Immun 2001;69(2):758-764.

89. Hickman-Davis J, Wang Z, Chess PR, Page GP, Matalon S, Notter RH. Surfactant dysfunction in SP-A-deficient and iNOS-deficient mice with mycoplasma infection. Am J Respir Cell Mol Biol 2007; 36(1):103-113.

90. Raghavendran K, Davidson BA, Knight PR, Wang Z, Helinski J, Chess PR, et al. Surfactant dysfunction in lung contusion with and without superimposed gastric aspiration in a rat model. Shock 2008; 30(5):508-517.

91. Lewis JF, Ikegami M, Jobe AH. Altered surfactant function and metabolism in rabbits with acute lung injury. J Appl Physiol 1990; 69(6):2303-2310.

92. Günther A, Siebert C, Schmidt R, Ziegle S, Grimminger F, Yabut $\mathrm{M}$, et al. Surfactant alterations in severe pneumonia, acute respiratory distress syndrome, and cardiogenic lung edema. Am J Respir Crit Care Med 1996;153(1):176-184.

93. Veldhuizen RAW, McCaig LA, Akino T, Lewis JF. Pulmonary surfactant subfractions in patients with the acute respiratory distress syndrome. Am J Respir Crit Care Med 1995;152(6 Pt 1):18671871.

94. Cockshutt A, Possmayer F. Lysophosphatidylcholine sensitizes lipid extracts of pulmonary surfactant to inhibition by plasma proteins. Biochim Biophys Acta 1991;1086(1):63-71.

95. Wang Z, Schwab U, Rhoades E, Chess PR, Russell DG, Notter RH. Peripheral cell wall lipids of mycobacterium tuberculosis are inhibitory to surfactant function. Tuberculosis (Ednib) 2008;88(3): 178-186.

96. Wang Z, Foye A, Chang Y, Chess PR, Wright TW, Bhagwat S, et al. Inhibition of surfactant activity by Pneumocystis carinii organisms and components in vitro. Am J Physiol Lung Cell Mol Physiol 2005;288(6):L1124-L1131.

97. Moses D, Holm BA, Spitale P, Liu M, Enhorning G. Inhibition of pulmonary surfactant function by meconium. Am J Obstet Gynecol 1991;164(2):477-481. 


\section{The Future of Exogenous Surfactant Therapy}

98. Pison U, Tam EK, Caughey GH, Hawgood S. Proteolytic inactivation of dog lung surfactant-associated proteins by neutrophil elastase. Biochim Biophys Acta 1989;992(3):251-257.

99. Holm BA, Kelcher L, Liu M, Sokolowski J, Enhorning G. Inhibition of pulmonary surfactant by phospholipases. J Appl Physiol 1991;71(1):317-321.

100. Enhorning G, Shumel B, Keicher L, Sokolowski J, Holm BA. Phospholipases introduced into the hypophase affect the surfactant film outlining a bubble. J Appl Physiol 1992;73(3):941-945.

101. Hickman-Davis JM, Fang FC, Nathan C, Shepherd VL, Voelker DR, Wright JR. Lung surfactant and reactive oxygen-nitrogen species: antimicrobial activity and host-pathogen interactions. Am J Physiol 2001;281(3):L517-L523.

102. Haddad IY, Ischiropoulos H, Holm BA, Beckman JS, Baker JR, Matalon S. Mechanisms of peroxynitrite-induced injury to pulmonary surfactants. Am J Physiol 1993;265(6 Pt 1):L555-L564.

103. Amirkhanian JD, Merritt TA. Inhibitory effects of oxyradicals on surfactant function: utilizing in vitro Fenton reaction. Lung 1998; 176(1):63-72.

104. Finkelstein JN. Physiologic and toxicologic response of alveolar type II cells. Toxicology 1990;60(1-2):41-52.

105. Finkelstein JN, Horowitz S, Sinkin RA, Ryan RM. Cellular and molecular responses to lung injury in relation to induction of tissue repair and fibrosis. Clinics in Perinatology 1992;19(3):603-620.

106. Mason RJ, Dobbs LG, Greenleaf RD, Williams MC. Alveolar type II cells. Fed Proc 1977;36:2697-2702.

107. Mason RJ, Williams MC. Alveolar type II cells. In: Crystal R, West JB, Weibel ER, Barnes, PJ, editors. The lung: scientific foundations. Philadelphia: Lipincott-Raven; 1997:235-246.

108. Seeger W, Pison U, Buchhorn R, Obestacke U, Joka T. Surfactant abnormalities and adult respiratory failure. Lung 1990;168(Suppl): 891-902.

109. Pison U, Seeger W, Buchhorn R, Joka T, Brand M, Obertacke U, et al. Surfactant abnormalities in patients with respiratory failure after multiple trauma. Am Rev Respir Dis 1989;140(4):1033-1039.

110. Gregory TJ, Longmore WJ, Moxley MA, Whitsett JA, Reed CR, Fowler AA, et al. Surfactant chemical composition and biophysical activity in acute respiratory distress syndrome. J Clin Invest 1991; 88(6):1976-1981.

111. Griese M. Pulmonary surfactant in health and human lung diseases: state of the art. Eur Respir J 1999;13(6):1455-1476.

112. Schmidt R, Markart P, Ruppert C, Wygrecka M, Kuchenbuch $T$, Walmrath $\mathrm{D}$, et al. Time-dependent changes in pulmonary surfactant function and composition in acute respiratory distress syndrome due to pneumonia or aspiration. Respir Res 2007;8:55.

113. Greene KE, Wright JR, Steinberg KP, Ruzinski JT, Caldwell E, Wong WB, et al. Serial changes in surfactant-associated proteins in lung and serum before and after onset of ARDS. Am J Respir Crit Care Med 1999;160(6):1843-1850.

114. Bernard GR, Artigas A, Brigham KL, Carlet J, Falke K, Hudson L, et al. The American-European Consensus Conference on ARDS. Definitions, mechanisms, relevant outcomes, and clinical trial coordination. Am J Respir Crit Care Med 1994;149(3 Pt 1):818-824.

115. Ware LB, Matthay MA. The acute respiratory distress syndrome. N Engl J Med 2000;342(18):1334-1348.

116. Knight PR, Rotta AT. Acute lung injury: etiologies and basic features. In: Notter RH, Finkelstein JN, Holm BA, editors. Lung injury: mechanisms, pathophysiology, and therapy. Boca Raton: Taylor \& Francis; 2005:67-110.

117. Artigas A, Bernard GR, Carlet J, Dreyfuss D, Gattinoni L, Hudson $\mathrm{L}$, et al. The American-European consensus conference on ARDS. Part 2: Ventilatory, pharmacologic, supportive therapy, study design strategies and issues related to recovery and remodeling. Intensive Care Med 1998;24(4):378-398.
118. Krafft P, Fridrich P, Pernerstorfer T, Fitzgerald RD, Koc D, Schneider $\mathrm{B}$, et al. The acute respiratory distress syndrome; definitions, severity, and clinical outcome. An analysis of 101 clinical investigations Intensive Care Med 1996;22(6):519-529.

119. Rubenfeld GD, Caldwell E, Peabody E, Weaver J, Martin DP, Neff $\mathrm{M}$, et al. Incidence and outcomes of acute lung injury. N Engl J Med 2005;353(16):1685-1693.

120. DeBruin W, Notterman DA, Magid M, Godwin T, Johnston S. Acute hypoxemic respiratory failure in infants and children: clinical and pathologic characteristics. Crit Care Med 1992;20(9):12231234.

121. Flori HR, Glidden DV, Rutherford GW, Matthay MA. Pediatric acute lung injury. Prospective evaluation of risk factors associated with mortality. Am J Respir Crit Care Med 2005;171(9):995-1001.

122. Dos Santos C, Slutsky A. Invited review: mechanisms of ventilatory induced lung injury: a perspective. J Appl Physiol 2000;89(4): 1645-1655.

123. Ricard J, Dreyfuss D, Saumon G. Production of inflammatory cytokines in ventilator induced lung injury: a reappraisal. Am J Respir Crit Care Med 2001;163(5):1176-1180.

124. The Acute Respiratory Distress Syndrome Network. Ventilation with lower tidal volumes as compared with traditional tidal volumes for acute lung injury and the acute respiratory distress syndrome. N Engl J Med 2000;342(18):1301-1308.

125. Pelosi P, Negrini D. Extracellular matrix and mechanical ventilation in healthy lungs: back to baro/volotrauma?. Curr Opin Crit Care 2008;14(1):16-21.

126. Spragg RG, Lewis JF, Wurst W, Hafner D, Baughman RP, Wewers $\mathrm{MD}$, et al. Treatment of acute respiratory distress syndrome with recombinant surfactant protein C surfactant. Am J Respir Crit Care Med 2003;167(11):1562-1566.

127. Spragg RG, Lewis JF, Walmrath HD, Johannigman J, Bellingan G, Laterre PF, et al. Effect of recombinant surfactant protein C-based surfactant on the acute respiratory distress syndrome. N Engl J Med 2004;351(9):884-892.

128. Lachmann B, Fujiwara T, Chida S, Morita T, Konishi M, Nakamura $\mathrm{K}$, et al. Surfactant replacement therapy in experimental adult respiratory distress syndrome (ARDS). In: Cosmi EV, Scarpelli EM, editors. Pulmonary surfactant system. Amsterdam: Elsevier; 1983: 221-235.

129. Kobayashi T, Kataoka H, Ueda T, Murakami S, Takada Y, Kobuko M. Effect of surfactant supplementation and end expiratory pressure in lung-lavaged rabbits. J Appl Physiol 1984;57(4):995-1001.

130. Berggren P, Lachmann B, Curstedt T, Grossmann G, Robertson B. Gas exchange and lung morphology after surfactant replacement in experimental adult respiratory distress induced by repeated lung lavage. Acta Anaesthesiol Scand 1986;30(4):321-328.

131. Lewis JF, Goffin J, Yue P, McCaig LA, Bjarneson D, Veldhuizen RAW. Evaluation of exogenous surfactant treatment strategies in an adult model of acute lung injury. J Appl Physiol 1996;80(4):11561164.

132. Walther F, Hernandez-Juviel J, Bruni R, Waring AJ. Protein composition of synthetic surfactant affects gas exchange in surfactantdeficient rats. Pediatr Res 1998;43(5):666-673.

133. Walther FJ, Hernandez-Juviel JM, Mercado PE, Gordon LM, Waring AJ. Surfactant with SP-B and SP-C analogs improves lung function in surfactant deficient rats. Biol Neonate 2002;82(3):181-187.

134. Gupta M, Hernandez-Juviel JM, Waring AJ, Bruni R, Walther FJ. Comparison of functional efficacy of surfactant protein B analogues in lavaged rats. Eur Respir J 2000;16(6):1129-1133.

135. Ruppert C, Kuchenbuch T, Boensch M, Schmidt S, Mathes U, Hillebrand V, et al. Dry powder aerosolization of a recombinant surfactant protein-C-based surfactant for inhalative treatment of the acutely inflamed lung. Crit Care Med 2010;38(7):1584-1591. 


\section{The Future of Exogenous Surfactant Therapy}

136. Krause M, Olsson T, Law AB, Parker RA, Lindstrom DP, Sundell $\mathrm{HW}$, et al. Effect of volume recruitment on response to surfactant treatment in rabbits with lung Injury. Am J Respir Crit Care Med 1997;156(3 Pt 1):862-866.

137. Krause MF, Jäkel C, Haberstroh J, Schulte-Mönting J, Leititis JU, Orlowska-Volk M. Alveolar recruitment promotes homogeneous surfactant distribution in a piglet model of lung injury. Pediatr Res 2001;50(1):34-43.

138. van Daal GJ, Eijking EP, So KL, Fievez RB, Sprenger MJW, van Dam DW, et al. Acute respiratory failure during pneumonia indeced by Sendai virus. Adv Exp Med Biol 1992;316:319-326.

139. van Daal GJ, Bos JAH, Eijking EP, Gommers D, Hannappel E, Lachmann B. Surfactant replacement therapy improves pulmonary mechanics in end-stage influenza A pneumonia in mice. Am Rev Respir Dis 1992;145(4 Pt 1):859-863.

140. Eijking EP, van Daal GJ, Tenbrinck R, Luyenduijk A, Sluiters JF, Hannappel E, et al. Effect of surfactant replacement on Pneumocystis carinii pneumonia in rats. Intensive Care Med 1990;17:475478.

141. Sherman MP, Campbell LA, Merritt TA, Long WA, Gunkel JH, Curstedt $\mathrm{T}$, et al. Effect of different surfactants on pulmonary group B streptococcal infection in premature rabbits. J Pediatr 1994;125(6 Pt 1):939-947.

142. Kobayashi T, Ganzuka M, Taniguchi J, Nitta K, Murakami S. Lung lavage and surfactant replacement for hydrochloric acid aspiration in rabbits. Acta Anaesthesiol Scand 1990;34(3):216-221.

143. Zucker A, Holm BA, Wood LDH, Crawford G, Ridge K, Sznajder IA. Exogenous surfactant with PEEP reduces pulmonary edema and improves lung function in canine aspiration pneumonitis. J Appl Physiol 1992;73:679-686.

144. Schlag G, Strohmaier W. Experimental aspiration trauma: comparison of steroid treatment versus exogenous natural surfactant. Exp Lung Res 1993;19:397-405.

145. Eijking EP, Gommers D, So KL, Vergeer M, Lachmann B. Surfactant treatment of respiratory failure induced by hydrochloric acid aspiration in rats. Anesthesiology 1993;78:1145-1151.

146. Tashiro K, Li W-Z, Yamada K, Matsumoto Y, Kobayashi T. Surfactant replacement reverses respiratory failure induced by intratracheal endotoxin in rats. Crit Care Med 1995;23(1):149-156.

147. Tashiro K, Yamada K, Li WZ, Matsumoto Y, Kobayashi T. Aerosolized and instilled surfactant therapies for acute lung injury caused by intratracheal endotoxin in rats. Crit Care Med 1996;24(3):488494.

148. Matalon S, Holm BA, Loewen GM, Baker RR, Notter RH. Sublethal hyperoxic injury to the alveolar epithelium and the pulmonary surfactant system. Exp Lung Res 1988;14(Suppl):1021-1033.

149. Matalon S, Holm BA, Notter RH. Mitigation of pulmonary hyperoxic injury by administration of exogenous surfactant. J Appl Physiol 1987;62(2):756-761.

150. Zhu GF, Sun B, Niu S, Cai YY, Lin K, Lindwall R, et al. Combined surfactant therapy and inhaled nitric oxide in rabbits with oleic acid-induced acute respiratory distress syndrome. Am J Respir Crit Care Med 1998;158(2):437-443.

151. Bellman G. Pathogenesis of oleic acid-induced lung injury in the rat: distribution of oleic acid during injury and early endothelial cell changes. Lipids 1995;39:817-823.

152. Nieman G, Gatto L, Paskanik A, Yang B, Fluck R, Picone A. Surfactant replacement in the treatment of sepsis-induced adult respiratory distress syndrome in pigs. Crit Care Med 1996;24(6): 1025-1033.

153. Lutz C, Carney D, Finck C, Picone A, Gatto L, Paskanik A, et al. Aerosolized surfactant improves pulmonary function in endotoxininduced lung injury. Am J Respir Crit Care Med 1998;158(3):840845 .
154. Willson DF, Thomas NJ, Markovitz BP, DiCarlo JV, Pon S, Jacobs $\mathrm{BR}$, et al. Effect of exogenous surfactant (calfactant) in pediatric acute lung injury: a randomized controlled trial. JAMA 2005;293(4): 470-476. Erratum in: JAMA 2005;294(8):900.

155. Lewis J, Ikegami M, Higuchi R, Jobe A, Absolom D. Nebulized vs. instilled exogenous surfactant in an adult lung injury model. J Appl Physiol 1991;71(4):1270-1276.

156. Lewis J, Ikegami M, Tabor B, Jobe A. Aerosolized surfactant is preferentially deposited in normal versus injured regions of the lung in a heterogeneous lung injury model (abstract). Am Rev Respir Dis 1992;145:A184

157. Lewis J, Veldhuizen RAW. Surfactant - current and potential therapeutic application in infants and adults. J Aerosol Med 1996;9(1): 143-154.

158. Lewis JF, Ikegami M, Jobe AH, Absolom D. Physiologic responses and distribution of aerosolized surfactant (Survanta) in a non-uniform model of lung injury. Am Rev Respir Dis 1993;147(6 Pt 1):1364-1370

159. Lewis JF, Ikegami M, Jobe AH, Tabor H. Aerosolized surfactant treatment of preterm lambs. J Appl Physiol 1991;70(2):869-876.

160. Schermuly R, Schmehl T, Günther A, Grimminger F, Seeger W, Walmrath D. Ultrasonic nebulization for efficient delivery of surfactant in a model of acute lung injury: impact on gas exchange. Am J Respir Crit Care Med 1997;156(2 Pt 1):445-453.

161. Schermuly RT, Günther A, Weissmann N, Ghofrani HA, Seeger W, Grimminger F, et al. Differential impact of ultrasonically nebulized versus tracheal-instilled surfactant on ventilation-perfusion mismatch in a model of acute lung injury. Am J Respir Crit Care Med 2000;161(1):152-159.

162. Ellyett KM, Broadbent RS, Fawcett ER, Campbell AJ. Surfactant aerosol treatment of respiratory distress syndrome in the spontaneously breathing premature rabbit. Pediatr Res 1996;39(6):953-957.

163. Dijk PH, Heikamp A, Oetomo SB. Surfactant nebulization versus Instillation during high frequency ventilation in surfactant-deficient rabbits. Pediatr Res 1998;44(5):699-704.

164. Wagner MH, Wiethoff S, Friedrich W, Mollenhauer I, Obladen M, Boenick U. Ultrasonic surfactant nebulization with different exciting frequencies. Biphysical Chem 2000;84(1):35-43.

165. Bahlmann H, Sun B, Nilsson G, Curstedt T, Robertson B. Aerosolized surfactant in lung-lavaged adult rats: factors influencing the therapeutic response. Acta Anaesthesiol Scand 2000;44(5):612-622.

166. Huang Y-CT, Caminiti SP, Fawcett TA, Moon RE, Fracica PJ, Miller FJ, et al. Natural surfactant and hyperoxic lung injury in primates. I. Physiology and biochemistry. J Appl Physiol 1994; 76(3):991-1001.

167. Fok TF, Al-Essa M, Dolovich M, Rasid F, Kirpalani H. Nebulisation of surfactants in an animal model of neonatal respiratory distress. Arch Dis Child Fetal Neonatal Ed 1998;78(1):F3-F9.

168. Lewis JF, Tabor B, Ikegami M, Jobe AH, Joseph M, Absolom D. Lung function and surfactant distribution in saline-lavaged sheep given instilled vs nebulized surfactant. J Appl Physiol 1993;74(3): 1256-1264.

169. Jorch G, Hartl H, Roth B, Kribs A, Gortner L, Schaible T, et al. Surfactant aerosol treatment of respiratory distress syndrome in spontaneously breathing premature infants. Pediatr Pulmonology 1997;24(3):222-224.

170. Finer NN, Merritt TA, Bernstein G, Job L, Mazela J, Liu G. A multicenter pilot study of Aerosurf ${ }^{\mathrm{TM}}$ delivered via nasal continuous positive airway pressure (nCPAP) to prevent respiratory distress syndrome in preterm neonates. Pediatr Res 2006;59.

171. Berggren E, Liljedahl M, Winbladh B, Andreasson B, Curstedt T, Robertson B, et al. Pilot study of nebulized surfactant therapy for neonatal respiratory distress syndrome. Acta Pædiatr 2000;89(4): $460-464$ 


\section{The Future of Exogenous Surfactant Therapy}

172. Arroe M, Pedersen-Bjergaard L, Albertsen P, Bode S, Greisen G. Inhalation of aerosolized surfactant (Exosurf) to neonates treated with continuous positive airway pressure. Prenat Neonat Med 1998; 3:346-352.

173. Shah S. Exogenous surfactant: intubated present, nebulized future? World J Pediatr 2011;7(1):11-15.

174. Marks LB, Notter RH, Oberdoerster G, McBride JT. Ultrasonic and jet aerosolization of phospholipids and the effects on surface activity. Pediatr Res 1984;17:742-747.

175. Marks LB, Oberdoerster G, Notter RH. Generation and characterization of aerosols of dispersed surface active phospholipids by ultrasonic and jet nebulization. J Aerosol Sci 1983;14:683-694.

176. Bjorklund LJ, Ingimarsson J, Curstedt T, Joseph J, Robertson B, Werner $\mathrm{O}$, et al. Manual ventilation with a few large breaths at birth compromises the therapeutic effect of subsequent surfactant replacement in immature lambs. Pediatr Res 1997;42(1-3):348-355.

177. Hillman NH, Moss TJM, Kallapur SG, Bachurski J, Pillow J, Polglase GR, et al. Brief, large tidal volume ventilation initiates lung injury and a systemic response in fetal sheep. Am J Respir Crit Care Med 2007;176(6):575-581.

178. Nilsson R, Grossman G, Robertson B. Bronchiolar epithelial lesions induced in the premature rabbit neonate by short periods of artificial ventilation. Acta Pathol Microbiol Scand 1980;88:359367.

179. Seidner SR, Ikegami M, Yamada T, Ryder ED, Castro R, Jobe AH. Decreased surfactant dose-response after delayed administration to preterm rabbits. Am J Respir Crit Care Med 1995;152(1):113-120.

180. Kendig JW, Notter RH, Cox C, Reubens LJ, Davis JM, Maniscalco WM, et al. A comparison of surfactant as immediate prophylaxis and as rescue therapy in newborns of less than 30 weeks gestation. N Engl J Med 1991;324(13):865-871.

181. Kattwinkel J, Bloom B, Delmore P, Davis C, Farrell E, Friss H, et al. Prophylactic administration of calf lung surfactant extract (CLSE) is more effective than early treatment of RDS in 29-32 weeks gestation babies. Pediatrics 1993;92(1):90-98.

182. van Der Beek J, Plotz F, van Overbeek F, Heikamp A, Beekhuis H, Wildevuur C, et al. Distribution of exogenous surfactant in rabbits with severe respiratory failure: the effect of volume. Pediatr Res 1993;34(2):154-158.

183. Segerer H, van Gelder W, Angenent FW, van Woerkens LJ, Curstedt T, Obladen M, et al. Pulmonary distribution and efficacy of exogenous surfactant in lung-lavaged rabbits are influenced by the instillation technique. Pediatr Res 1993;34(4):490-494.

184. Hartog A, Gommers D, Haitsma JJ, Lachmann B. Improvement of lung mechanics by exogenous surfactant: effect of prior application of high positive end-expiratory pressure. Br J Anaesth 2000;85(5): 752-756

185. Kesecioglu J, Beale R, Stewart TE, Findlay GP, Rouby J-J, Holzapfel L, et al. Exogenous natural surfactant for treatment of acute lung injury and the acute respiratory distress syndrome. Am J Respir Crit Care Med 2009;180(10):989-994.

186. Günther A, Schmidt R, Harodt J, Schmehl T, Walmrath D, Ruppert $\mathrm{C}$, et al. Bronchoscopic administration of bovine natural surfactant in ARDS and septic shock: impact on biophysical and biochemical surfactant properties. Eur Respir J 2002;19(5):797-804.

187. Walmrath D, Gunther A, Ghofrani HA, Schermuly R, Schnedier T, Grimminger F, et al. Bronchoscopic surfactant administration in patients with severe adult respiratory distress syndrome and sepsis. Am J Respir Crit Care Med 1996;154(1):57-62.

188. Walmrath D, Grimminger F, Pappert D, Knothe C, Obertacke U, Benzing A, et al. Bronchoscopic administration of bovine natural surfactant in ARDS and septic shock: impact on gas exchange and haemodynamics. Eur Respir J 2002;19(5):805-810.
189. Spragg R, Gilliard N, Richman P, Smith R, Hite R, Pappert D, et al. Acute effects of a single dose of porcine surfactant on patients with the adult respiratory distress syndrome. Chest 1994;105(1):195202.

190. Wiswell TE, Smith RM, Katz LB, Mastroianni L, Wong DY, Willms D, et al. Bronchopulmonary segmental lavage with Surfaxin (KL(4)surfactant) for acute respiratory distress syndrome. Am J Respir Crit Care Med 1999;160(4):1188-1195.

191. Willson DF, Jiao JH, Bauman LA, Zaritsky A, Craft H, Dockery K, et al. Calf lung surfactant extract in acute hypoxemic respiratory failure in children. Crit Care Med 1996;24(8):1316-1322.

192. Willson DF, Bauman LA, Zaritsky A, Dockery K, James RL, Stat $\mathrm{M}$, et al. Instillation of calf lung surfactant extract (calfactant) is beneficial in pediatric acute hypoxemic respiratory failure. Crit Care Med 1999;27(1):188-195.

193. López-Herce J, de Lucas N, Carrillo A, Bustinza A, Moral R. Surfactant treatment for acute respiratory distress syndrome. Arch Dis Child 1999;80(3):248-252.

194. Hermon MM, Golej J, Burda H, Boigner H, Stoll E, Vergesslich K, et al. Surfactant therapy in infants and children: three years experience in a pediatric intensive care unit. Shock 2002;17(4):247-251.

195. Herting E, Moller O, Schiffman JH, Robertson B. Surfactant improves oxygenation in infants and children with pneumonia and acute respiratory distress syndrome. Acta Paediatr 2002;91(11): 1174-1178.

196. Auten RL, Notter RH, Kendig JW, Davis JM, Shapiro DL. Surfactant treatment of full-term newborns with respiratory failure. Pediatrics 1991;87(1):101-107.

197. Luchetti M, Casiraghi G, Valsecchi R, Galassini E, Marraro G. Porcine-derived surfactant treatment of severe bronchiolitis. Acta Anaesthesiol Scand 1998;42(7):805-810.

198. Luchetti M, Ferrero F, Gallini C, Natale A, Pigna A, Tortorolo L, et al. Multicenter, randomized, controlled study of porcine surfactant in severe respiratory syncytial virus-induced respiratory failure. Pediatr Crit Care Med 2002;3(3):261-268.

199. Moller JC, Schaible T, Roll C, Schiffmann JH, Bindl L, Schrod L, et al. Treatment with bovine surfactant in severe acute respiratory distress syndrome in children: a randomized multicenter study. Intensive Care Med 2003;29(3):437-446.

200. Amital A, Shitrit D, Raviv Y, Saute M, Medalion B, Bakai L, et al. The use of surfactant in lung transplantation. Transplantation 2008; 86(11):1554-1559.

201. Kermeen FD, McNeil KD, Fraser JF, McCarthy J, Ziegenfuss MD, Mullarny D, et al. Resolution of severe ischemia-reperfusion injury post-lung transplantation after administration of endobronchial surfactant. J Heart Lung Transplant 2007;26(8):850-856.

202. Della Rocca G, Pierconti F, Costa MG, Coccia C, Pompei L, Rocco $\mathrm{M}$, et al. Severe reperfusion lung injury after double lung transplantation. Crit Care 2002;6(3):240-244.

203. Strüber M, Fischer S, Niedermeyer J, Warnecke G, Gohrbandt B, Gorler A, et al. Effects of exogenous surfactant instillation in clinical lung transplantation: a prospective, randomized trial. J Thorac Cardiovasc Surg 2007;133(6):1620-1625.

204. Strüber M, Hirt SW, Cremer J, Harringer W, Haverich A. Surfactant replacement in reperfusion injury after clinical lung transplantation. Intensive Care Med 1999;25(8):862-864.

205. Varisco BM, Palmatier CM, Alten JA. Reversal of intractable hypoxemia with exogenous surfactant (calfactant) facilitating complete neurological recovery in a pediatric drowning victim. Pediatr Emerg Care 2010;26(8):571-573.

206. Holopainen R, Aho H, Laine J, Peuravuori H, Soukka H, Kääpä P. Human meconium has high phospholipase $\mathrm{A}_{2}$ activity and induces cellular injury and apoptosis in piglet lungs. Pediatr Res 1999; 46(5):626-632. 
207. Clark DA, Nieman GF, Thompson JE, Paskanik AM, Rokhar JE, Bredenberg CE. Surfactant displacement by meconium free fatty acids: an alternative explanation for atelectasis in meconium aspiration syndrome. J Pediatr 1987;110(5):765-770.

208. Notter RH, Finkelstein JN, Holm BA. Lung injury: mechanisms, pathophysiology and therapy. Boca Raton: Taylor \& Francis; 2005.

209. Caironi P, Langer T, Gattinoni L. Acute lung injury/acute respiratory distress syndrome pathophysiology: what we have learned from computed tomography scanning. Curr Opin Crit Care 2008;14(1): 64-69.
210. Gattinoni L, Bombino M, Pelosi P, Lissoni A, Pesente A, Fumagalli $\mathrm{R}$, et al. Lung structure and function in different stages of severe adult respiratory distress syndrome. JAMA 1994;271(22):17721779 .

211. Gattinoni L, Pesenti A. The concept of the "baby lung". Intensive Care Med 2005;31(6):776-784.

212. Pryhuber GS, D'Angio CT, Finkelstein JN, Notter RH. Combinedmodality therapies for lung injury. In: Notter RH, Finkelstein JN, Holm BA, editors. Lung injury: mechanisms, pathophysiology, and therapy. Boca Raton: Taylor \& Francis; 2005:779-838.

\section{Discussion}

DiBlasi: Of the 4 surfactant studies you mentioned that were not in premature infants, ${ }^{1-4}$ were there any noteworthy differences in the ventilation modes or the approach to mechanical ventilation?

1. Anzueto A, Baughman RP, Guntupalli KK, Weg JG, Wiedemann HP, Raventós AA, et al. Aerosolized surfactant in adults with sepsis-induced acute respiratory distress syndrome. Exosurf Acute Respiratory Distress Syndrome Sepsis Study Group. N Engl J Med 1996;334(22):1417-1421.

2. Spragg RG, Lewis JF, Walmrath HD, Johannigman J, Bellingan $\mathrm{G}$, Laterre $\mathrm{PF}$, et al. Effect of recombinant surfactant protein C-based surfactant on the acute respiratory distress syndrome. $\mathrm{N}$ Engl $\mathrm{J}$ Med 2004;351(9):884-892.

3. Kesecioglu J, Beale R, Stewart TE, Findlay GP, Rouby JJ, Holzapfel L, et al.Exogenous natural surfactant for treatment of acute lung injury and the acute respiratory distress syndrome.Am J Respir Crit Care Med 2009; 180(10):989-994.

4. Spragg RG, Taut FJ, Lewis JF, Schenk P, Ruppert C, Dean N, et al. Recombinant surfactant protein C-based surfactant for patients with severe direct lung injury.Am J Respir Crit Care Med 2011;183(8):10551061.

Willson: They used ventilation protocols, but I don't recall the details of them, and only the last two studies used low $\mathrm{V}_{\mathrm{T}}$. Roger Spragg has always been involved with the Acute Respiratory Distress Syndrome Network, and his studies have used low $\mathrm{V}_{\mathrm{T}}$. Lachmann's group also used a ventilation protocol that they said was modeled after the Acute Respiratory Distress Syndrome Network low- $\mathrm{V}_{\mathrm{T}}$ strategy. So, other than the first study, I think yes, they were fairly comparable in terms of how they were managed.

Curley: Thank you for all of the work you've done over the years. You've been a pioneer and a colleague to many who've walked behind you. You are always there with good suggestions and are very generous with your work.

I think surfactant ought to be used in certain subpopulations You can't deny some of these cases. Which of the diagnoses are more responsive to surfactant?

Willson: The devil is in the details. Distribution is a big issue. We have to work out the details regarding administration. The data are very sparse. What volume? What dose? How often? How exactly is it given? The difference between our 3 previous studies $^{1-3}$ and this study (Calfactant for direct acute respiratory distress syndrome [CARDS] trial. http://clinical trials.gov/ct2/show/NCT00682500) relate to how it was given-not so much the patient population.

The first question I want to answer is how do we best administer it? After that, the data that we have say that it is most helpful in direct lung injury. In my own experience-and I do give it off-label when we're not involved in studies-I've seen kids in whom surfactant is like a resurrection. The very first kid I gave it to I thought was going to be on ECMO by the evening, and he was extubated 2 days later. And I've also had kids in whom it did absolutely nothing.
It's possible that there are differences in concentration, strength, et cetera, because it's a biological product. It's a very complex issue. But some of the details we've talked about are important, and I think that's the first thing. Once we figure out if there are differences in how it's distributed, depending on how you give it, then the next thing will be to look at the patient populations.

1. Willson DF, Jiao JH, Bauman LA, Zaritsky A, Craft H, Dockery K, et al.: Calf's lung surfactant extract in acute hypoxemic respiratory failure in children. Crit Care Med 1996;24(8):1316-1322.

2. Willson DF, Zaritsky A, Bauman LA, Dockery K, James RL, Conrad D, et al. Instillation of calf's lung surfactant Extract (Infasurf) is beneficial in pediatric acute hypoxemic respiratory failure. Members of the Mid-Atlantic Pediatric Critical Care Network. Crit Care Med 1999; 27(1):188195.

3. Willson DF, Thomas NJ, Markovitz BP, Bauman LA, DiCarlo JV, Pons S, et al. Effect of exogenous surfactant (calfactant) in pediatric acute lung injury: a randomized controlled trial. JAMA 2005; 293(4): 470-476. Erratum in JAMA. 2005;294(8): 900.

Curley: Maybe it's in the biological processes, and we just don't know enough about the processes that we're administering the product in?

Willson: There's no question about that. There are different types of surfactant, and it is not a simple substance.There are multiple phospholipids, neutral lipids, and surfactant proteins, all of which have to come together to be effective, and that may be one of the problems with aerosolization. 
Wiswell: Doug, I'm intrigued by the concept of administering dilute surfactant via lung lavage. I was involved with a study in the late 1990s in adults, in which surfactant was delivered via bronchoscopy to the individual pulmonary segments. ${ }^{1}$ We had some glimmers of success, but the follow-up trial fell through. I was subsequently involved in a small trial in which we directly lavaged the lungs, via the ETT, of neonates with meconium aspiration syndrome. ${ }^{2}$ We also had some glimmers there.

We subsequently performed a larger trial in meconium aspiration syndrome with this technique. Unfortunately, the pharmaceutical company sponsoring that trial has kept all the data under wraps, as they concentrated on the RDS population in their attempt to get FDA approval of their surfactant. Recently the Australia/New Zealand study $^{3}$ used a similar approach in babies with meconium aspiration syndrome, lavaging the lungs with dilute surfactant. The lavaged group had lower mortality and were less likely to need ECMO.

Thus, I' $m$ wondering if with certain disorders the lavage approach may be a better way to administer surfactant. When I think of ALI/ARDS or meconium aspiration syndrome, I think of the crap inside the lungs, including inflammatory products and other material that deactivates surfactant. It seems logical to wash out that debris and leave behind some functioning surfactant, if we can do it without harming the patient. Adults are bigger, so you can bronchoscope them easier than you can kids. On the other hand, one can lavage a baby directly via the ETT a lot easier than you can a 4-year-old or 8-year-old. Any thoughts on administration?

1. Wiswell TE, Smith RM, Katz LB, Mastroianni L, Wong DY, Willms D, et al. Bronchopulmonary segmental lavage with Surfaxin (KL(4)-surfactant) for acute respiratory distress syndrome. Am J Respir Crit Care Med 1999;160(4):11881195.
2. Wiswell TE, Knight GR, Finer NN, Donn SM, Desai H, Walsh WF, et al. A multicenter, randomized, controlled trial comparing Surfaxin (Lucinactant) lavage with standard care for treatment of meconium aspiration syndrome. Pediatrics 2002; 109(6):1081-1087.

3. Dargaville PA, Copnell B, Mills JF, Haron I, Lee JK, Tingay DG, et al; lessmeconium aspiration syndrome Trial Study Group. Randomized controlled trial of lung lavage with dilute surfactant for meconium aspiration syndrome. J Pediatr.2011;158(3): 383-389.e2.

Willson: There have been some uncontrolled studies, and it does make intuitive sense, particularly if distribution is a major problem: it makes intuitive sense to deliver it via bronchoscopy. From a practical point of view it would require a lot more effort to do, so I fear that study will never be done. The study you're referring to had about 90 adults, which for an adult study is small. ${ }^{1}$ One important problem with any clinical study in children is that the standard is about a $10 \%$ mortality, and that's going to be hard to beat, particularly the morbidity associated with just intubating, general anesthesia, and bronchoscopy in a small child or baby. I think we're going to have to look at it some other way. Some of the problem with debris in the lung undoubtedly develops over time, but if you could give surfactant early down the ETT I think it might help. And it may not be so much who but when: 3 days into the disease there may already be severe VILI and severe heterogeneity in the lung, and then it's too late.

1. Gregory TJ, Hicklin G, Willms D, Fletcher EC, Hite RD, et al. Lucinactant bronchopulmonary segmental lavage (BPSL) in patients with ARDS. Presented at The American Thoracic Society International Conference 2007; May 18-23, San Francisco, CA.

Walsh: I want to confirm your thought about recruitment. I participated as a dosing administrator in your study, and I remember hearing the care team (who was blinded to the study drug) look at the oxygen saturation and state, "Oh, this kid got surfactant!" when I knew that patient got a sham dose. I couldn't say anything, but I remember that vividly in at least 2 patients. I think there's potentially something there. When you're talking about giving it early, how early is early? Would you consider using a laryngeal mask airway and then putting them back on noninvasive ventilation?

Willson: Like the neonates? I think the solution would be to aerosolize it, then give via noninvasive ventilation. Unfortunately, aerosolization hasn't been successful so far. If I knew which way a kid was headed, I'm sure I wouldn't hesitate to use it early, particularly if you could effectively aerosolize it. If it were my own child, that's what I would do.

But you know, Brian, if you look at a kid admitted with pneumonia, for example, early on it is difficult to determine their clinical trajectory, so getting approval for a study to treat nonintubated children seems unlikely. I think the best we can do, since aerosolization doesn't seem to work, would be to conduct a study in which the surfactant is instilled immediately after intubation. This would allow the best possible distribution and the possibility of avoiding some of the positive-pressure-associated lung injury, and would be the best test of whether instilled surfactant is helpful.

Rubin: Actually, surfactant has been successfully aerosolized into humans and produced a benefit. We published a COPD trial in JAMA that showed significant mobilization of secretions and improvement in pulmonary function. ${ }^{1}$ A similar study was done in persons with cystic fibrosis. So there may be different end points when used as an ambulatory therapy. 
1. Anzueto A, Jubran A, Ohar JA, Piquette CA, Rennard SI, Colice G, et al. Effects of aerosolized surfactant in patients with stable chronic bronchitis. A prospective randomized controlled trial. JAMA 1997; 278(17):1426-1431

Willson: What were the end points in that study?

Rubin: Pulmonary function, secretion biophysical properties and transportability, and gas trapping as measured via $\mathrm{D}_{\mathrm{LCO}}$ [diffusing capacity of the lung for carbon monoxide].

Willson: I was not aware of those data. Which surfactant was it?

Rubin: The study was done a long time ago. It was Exosurf. I was the senior author.
Willson: Interesting. An incomplete surfactant to say the least. Thank you.

Curley: Doug, in the current study (Calfactant for direct acute respiratory distress syndrome [CARDS] trial. http://clinicaltrials.gov/ct2/show/ NCT00682500) what was the number of patients enrolled per site?

Willson: In the pediatrics study I think it was 32 . In the adult study there were about 60 .

Curley: And the number enrolled per site?

Willson: Some sites, as you can imagine, only had one. Omaha Children's had 18, I think. There was a wide range of numbers
Curley: It might be interesting to take away the first 3 or 4 patients and look at the data after that, because it is operator-dependent, and even in the activated protein- $\mathrm{C}$ trial the first 3 or 4 patients per site showed different outcomes than those who followed. It shows that expertise at the bedside matters.

Willson: I appreciate the suggestion. We're trying to determine if there is a patient population that responds acutely and whether there are differences between the sites. Some of that will depend on how many different patients you enroll in the study. We're also beginning to look at the adult data and whether there are differences between the children and adults. My guess is not, but we'll see. 